\title{
Importance of buildings and their influence in control system: a simulation case study with different building standards from Germany
}

\author{
Muthalagappan Narayanan $^{1}$ (1) $\cdot$ Gerhard Mengedoht ${ }^{1} \cdot$ Walter Commerell $^{1}$
}

Received: 6 April 2018 / Accepted: 31 July 2018 / Published online: 9 August 2018

(c) The Author(s) 2018

\begin{abstract}
Buildings play an important role in the energy consumption of a household. There are different types of buildings and different standards, which are for each of them. Hence, the decentralized energy system has different configurations for each building standards and buildings built up according to each standards and have necessity to be controlled in a different approach. Using a case study of four different standards-Sonnenhaus, KfW55, Passive house and WSchVO95 of single family houses (SFH) of same geometry and boundary conditions the control constraints are showcased. The houses are selected such that high renewable energy self-production, low energy demand house, low net energy house and an old 1995 constructed house are compared. The differences in the system design, their control strategy and how it affects the system sizing or renewable fraction is explained in this paper. The same SFH according to different standards is simulated with TRNSYS and the energy system (including solar thermal collectors, PV, gas boiler, fuel cell CHP, thermal storage and electrical storage) for each house is optimized and compared. Thus, the paper showcases the importance of the building, not only geometry but also building physics and energy efficiency. Finally, the necessity for intelligent control system for a complicated building system with multiple energy source is justified and the requirements of such control systems are enlisted.
\end{abstract}

Keywords Building control · Intelligent home energy system · TRNSYS · Building standards · Germany

\section{Introduction}

As already mentioned in a lot of instances, the [1] report estimates that around $40 \%$ of the world's final energy is used for residential buildings. The building sector plays a large role in the energy consumption which includes space heating or cooling, domestic hot water and electricity. Buildings with their long lifespan and huge amount of already existing buildings, makes revision in energy characteristics of a building constrained. In many countries, new buildings could be made $70 \%$ more efficient than existing buildings [2]. According to [3], the annual rate of new building construction is always higher than the demolition rate. In contrary to the energy policies' aims of reducing the energy consumption, the energy demand in residential sector has

Muthalagappan Narayanan

narayanan@hs-ulm.de

1 Institute of Energy and Drive Technology, Ulm University of Applied Sciences, Ulm, Germany increased by $15 \%$ in the last decade in UK [4]. Global energy consumption in the residential sector grows on average at $1 \%$ per year [2]. Energy use in the buildings sector follows a trend which increases it by $88 \%$ between 2003 and 2050, or $1.4 \%$ per year [2]. A whopping $50 \%$ of residential sector demand is used for space heating in IEA countries and this is expected to be around $70 \%$ for countries such as Germany and Poland [1]. The second major energy demand for residential sector is the electricity. Electricity consumption increases at $2.5 \%$ per year, raising its share in the buildings sector from $24 \%$ in 2003 to estimated $40 \%$ in 2050 [2, p. 200]. Half of all energy saving potential in the residential sector could be from space heating [2]. Water heating also accounts for about $16 \%$ of total energy savings in the future [2]. Accordingly, the most effective energy conservation measures are the insulation of external walls (33-60\% energy savings), weather proofing of openings (16-21\%), the installation of double-glazed windows (14-20\%), the regular maintenance of central heating boilers (10-12\%), and the installation of solar collectors for sanitary hot water production (50-80\%) [5]. 
The buildings in Germany share a large part of the total energy consumption and since 1979 there has been standards to be followed for new buildings and renovations. According to [3], there are 18.6 million residential buildings in Germany and of which $83 \%$ are single or 2 family houses (47\% of the German families live in SFH and 2FH). $64 \%$ of these single or 2 family houses are built before 1979 and therefore in total there are $65 \%$ of residential buildings which are erected before any standard was in place and $39 \%$ of those are built between 1950s and 1970s [3]. It is also calculated that only $33 \%$ of these old SFHs are renovated [3, $6]$. The windows $(60 \%)$ and the roof $(65 \%)$ are the most reconstructed parts of the building and still the walls are not given that much of importance with only $35 \%$ of the renovations considered to improve the $U$ value of the walls [3]. The basement insulation is the least renovated with $20 \%$ [3]. According to [3], there is only $1-1.2 \%$ increase in the renovation trend each year and only $4 \%$ of these renovations are full renovation of the buildings. SFHs as an average require $152 \mathrm{kWh} / \mathrm{m}^{2}$ a end energy and it has just reduced $13 \%\left(21 \mathrm{kWh} / \mathrm{m}^{2} \mathrm{a}\right)$ in the last 6 years [3]. Dena [3] also showed that $80 \%$ of the energy demand in a residential building sector is used in heating and only $15 \%$ of this heating demand is delivered by renewable energy while still $46 \%$ is via gas. When the installed thermal energy producers are closely compared between 1998 and 2013, the 13\% of the oil's share is now substituted by heat pump and biomass but the gas units are still more or less in the same share of $70 \%$ [3]. Surprisingly, [3] also states that in the newly built buildings still $51 \%$ are gas boilers and 30\% heat pumps and only $1 \%$ is solar thermal and the trend is reducing since 2011 for the yearly installed solar thermal systems. The application of renewable systems into buildings is the next step to sustainable future and there are already many research going on in integration of renewable and their benefits in buildings, such are the articles from Enteria et al. [7], which showed how the renewable systems can be integrated into single family houses in Philippines and why all buildings are not the same. Enteria et al. [8] also showed the benefits of utilizing the renewables in single family houses.

The control system for buildings plays an important role and with developments in control strategy around $10-20 \%$ of the energy use can be reduced [1]. Regardless of white, gray or black box model of the controllers, the building plays an important role. The crucial part of building modelling in the predictive control is explained in [9]. The building as storage and the energy demand variance between different air tightness and insulation is showed in [10]. Yu et al. [11] listed building system control in three categories: classical control (mainly on/off and PID); soft or intelligent control (based on historical data); and hard or advanced control (based on building model). As described in [12], the model free control strategies use the weather predictions without any building or historical data which manipulate the heating or cooling system or the temperature set points. These are easy to implement, low cost but limited results. The intelligent controllers use a kind of fuzzy logic or a set of rules which are created from the monitoring or current building data [13]. The ability is high, but experienced user is required to set the logical rules and is different for each scenario and the logic is required to be developed from scratch for each building application. The advanced control uses the building model in the control operation. In [12], advanced control is further divided into adaptive, optimal and model predictive control. Adaptive is based on the adjustment of model parameters [14] and optimal controllers find an optimal setting for the parameters which is being adjusted to an optimum of a control strategy [15]. Model predictive control (MPC) does the optimal control with some predictions. Other than these control methods are the non-optimal advanced controls which make the best of the situation even though it is not optimal (e.g., heating the building using electricity when PV is working with certain boundary conditions) $[12,16]$.

The main parameters usually for a MPC are thermal comfort, peak energy consumption, total energy consumption and applicability of renewable energy sources [16]. The most of the MPCs which are researched for now are specific to that building and may not be the optimal for similar building or application. Due to this the cost of implementing such MPCs are high and the uncertainties further increases when they use the gray or black box models. And for white box models, the building is modelled in a software (TRNSYS, EnergyPlus) in which the optimization has to be carried out in another software (Matlab, GenOpt) and the computing time is high. Hence, in such cases where simulated building model is used for control, they are very specific and the manipulated variables are mostly the set point or on/off of the energy systems. In other cases, the renewable production forecast, the energy system and storage is controlled for optimal operation and the demand forecast is carried out. But in most of the researched cases or implemented MPCs the solution is not universal, thus mass optimization logic is not yet achieved. The necessity of such systems is being showcased in this paper where the control unit can use a learning process to utilize the MPC optimally and manipulate the required variables to achieve an optimal strategy in any kind of building after understanding them and the algorithm will be universally viable which of course can be mass produced and will reduce the implementation cost. But the problem with such universal MPC stay in the demand side where the building's heating demand is not only different but also fall on the dependency on buildings response, thermal comfort zone, different sizing and components of the energy system. This paper tries to showcase the buildings' and their standard's importance in sizing of the energy system. In addition, the control strategy of different building standard differs in 
accordance to their energy demand, heat storage capability and energy system size.

The role of controllers in building heating or in renewable systems has already been identified. For example, a MPC controller was implemented in a Swiss office building in [17] but they customized the MPC for that particular building and also showcased this causes the cost for such controllers to be too high to be put in use. In addition, MPC was introduced in energy storage system using weather forecast and this was reviewed in the literatures of Thieblemont et al. [12] and Zhun et al. [11]. But what still remains open is the combination of energy systems, the storage and building all together into a single system controller and universalization of this controller. In most of the literature, the MPC is customized and designed especially for the special case and the ultimate aim of the project is to develop a controller hierarchy or a management where all controllers will communicate with each other and work optimally using MPC via energy and demand forecast and learn from the system such that it can be universally adaptive.

The work is partially a part of the project intelligent home energy management (iHEM), more info at [18]. The main objective of this project is to integrate thermal and electrical components with more energy sources at high efficient operation in a household for high self-utilization. For an intelligent control of such system, the load and production energy are forecasted and an optimum predictive operation strategy is found out so that the system is not only efficiently optimized and self-utilization prioritized with maximum possible renewable energy ratio but also economically and strategically viable. The subjective goal of the project is to have an integrated home energy system communicating to all the components through a superior management component. In accordance with this project, in paper [19], the simulation of the novel simulation model of the storage tank with lances is discussed and in [20] the simulation of the entire energy system (building, thermal and electrical system) modelling in TRNSYS is explained along with the assumptions simplifications and limitations for the simulation model. The electrical model has then been developed to a three-phase model. A small description of the simulation is given in the section below but a detailed one can be found in [20]. The previous works done [19-21] in this project can also provide a background of this work.

The challenge to be addressed here is to develop a universal control logic which could be installed in a house where regardless of renewable system and the building characteristic, the control unit should function optimally and work harmonically in coherence with the energy system and building. The ultimate aim of the project is to build a MPC simulation model with energy system and building in TRNSYS and to develop a control logic using hardware in the loop (HiL) tests. These HiL tests would be used to answer questions like which system configuration works better with which building type or standard with special focus on German buildings and energy demand types.

\section{Methodology}

This paper strives to point out the working inabilities of the current control logics in the current building energy systems and the required advances in that field by pinpointing the differences in the building responses and why all buildings are not the same; what is the required control changes to integrate renewables so as to utilize the renewables effectively and why the control approach for different buildings must vary. In this simulation case study, four different building standards in Germany from vast building standards are taken. These four building types are Sonnenhaus, KfW55, Passive house and WSchVO95. All these house types have different energy demands, different building characteristics and range not only from old house (WSchVO95) to new (KfW55) but also from less energy requirement (Passive house) to high solar energy fraction (Sonnenhaus). The buildings have the same building geometry or structure and only the building envelope's details are changed according to the requirement of each of the building type. All the buildings are single family houses with same geometry but in accordance with each standard.

The building characteristics of the base case are taken directly from a real KfW55 Building [22]. The KfW55 building is made available from Dammann-Haus $\mathrm{GmbH}$ Company and the total $U$ value of the building is 0.18 . The other three building models are developed with the same building envelope dimensions and just by changing the characteristics of the walls and the required building standard conditions. As previously mentioned, the paper will focus only on single family house. The house being modelled is with a useable area of $183 \mathrm{~m}^{2}$ and a gross volume of $567 \mathrm{~m}^{3}$ with the envelope as shown in Fig. 1. The house has in total two floors and an unheated roof store room. The roof is $63 \mathrm{~m}^{2}$ in each side facing North-South and the unheated roof together is $35 \mathrm{~m}^{2}$. The floor of this unheated zone is $52 \mathrm{~m}^{2}$. The two floors of the heated building are taken as a single zone. The building is structured in SketchUp and is coupled in TRNSYS with the energy system. The fuel cell CHP is modelled in Matlab and is coupled in TRNSYS. The thermal and electrical system with space heating, hot water demand and electricity demand is simulated in TRNSYS.

The building is assumed to be occupied by four people during 22:00-08:00 and by one person during 08:00-13:00 and from 13:00 proportionally the three persons coming in. The shade for the buildings is put on when temperature outside is above $24^{\circ} \mathrm{C}$ to reduce solar gains. The windows are also opened for a forced ventilation when temperature is 
Fig. 1 The building envelope as modelled in SketchUp southeast orientation in the left and north-west view in the right

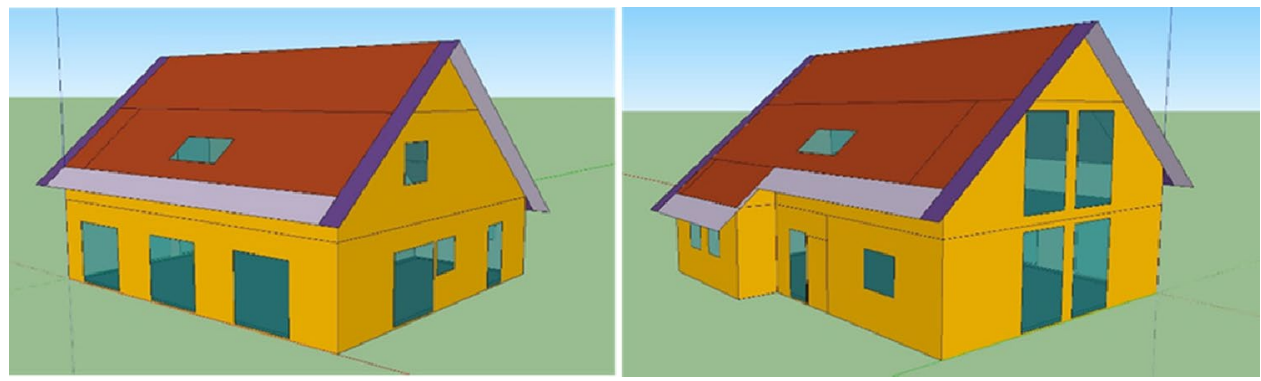

above $26{ }^{\circ} \mathrm{C}$. The building has $9,7.42,16$ and $1.6 \mathrm{~m}^{2}$ window area in south, east, west and north. The more on dimensions and characteristics of the building can be found in [22].

The single family house is assumed to be occupied by four members in all scenarios and the electrical load profile is taken from VDI4655 Norm profile [23]. This profile is being taken from real measurements in one minute intervals. The measurements are done on ten different typical days combining clear and cloudy; summer, winter and transition season; working day and holiday. With those typical days, the annual demand is compiled. The consumption was measured in 15 different climate zones in Germany. The profile is made available in nominated value which has to be customized with the number of occupants and the climate zone. The DHW profile and the electricity demand profile is being developed from this profile. For the simulation the SFH building with 4 occupants is assumed to have $500 \mathrm{kWh}$ per person per year for hot water consumption and a total of $4140 \mathrm{kWh}$ as electrical consumption. More about the demand curve can be found at [23]. For the other standards, the building data are also taken from the real building of that particular standard. Using the KfW55 building geometry, the building simulation model is created. Thus, being easily comparable with one another.

The climate in Ulm is a mid-European cold of a kind. As shown in Fig. 2, a weather data from year 2013 is used for simulation. The temperatures go up to $-15^{\circ} \mathrm{C}$ in February winter peak and staying sub-zero for most of the winter as an average during the months November-February. During these months, due to low sun angle and less sun hours not much of solar gains are achieved. But in summer, the average goes above $15{ }^{\circ} \mathrm{C}$ with peak mid-day up to $30{ }^{\circ} \mathrm{C}$ on some days. The house temperature is set at $20{ }^{\circ} \mathrm{C}$ for which the heating control works on with $\mathrm{a} \pm 1^{\circ} \mathrm{C}$ and a night temperature reduction of $16^{\circ} \mathrm{C}$ during 22:00-06:00.

\section{Requirements of the building standard}

\section{KfW55}

The KfW55 [24] is an efficient house standard for which a lot of incentives and financial support is made available. The yearly primary energy should be more than $55 \%$ of the EnEV Standard requirement. The specific transmission losses should not exceed $70 \%$ of the EnEV reference building. One of the other important requirements is that there should be a heat recovery enabled forced ventilation for the building and there should be a blower door test done.

\section{Sonnenhaus}

The Sonnenhaus standard [25] is a special certificate given for houses which has a solar fraction of $50 \%$ for the thermal demand of the building (space heating and hot water
Fig. 2 Weather of Ulm, Germany on year 2013 for which the simulation is done

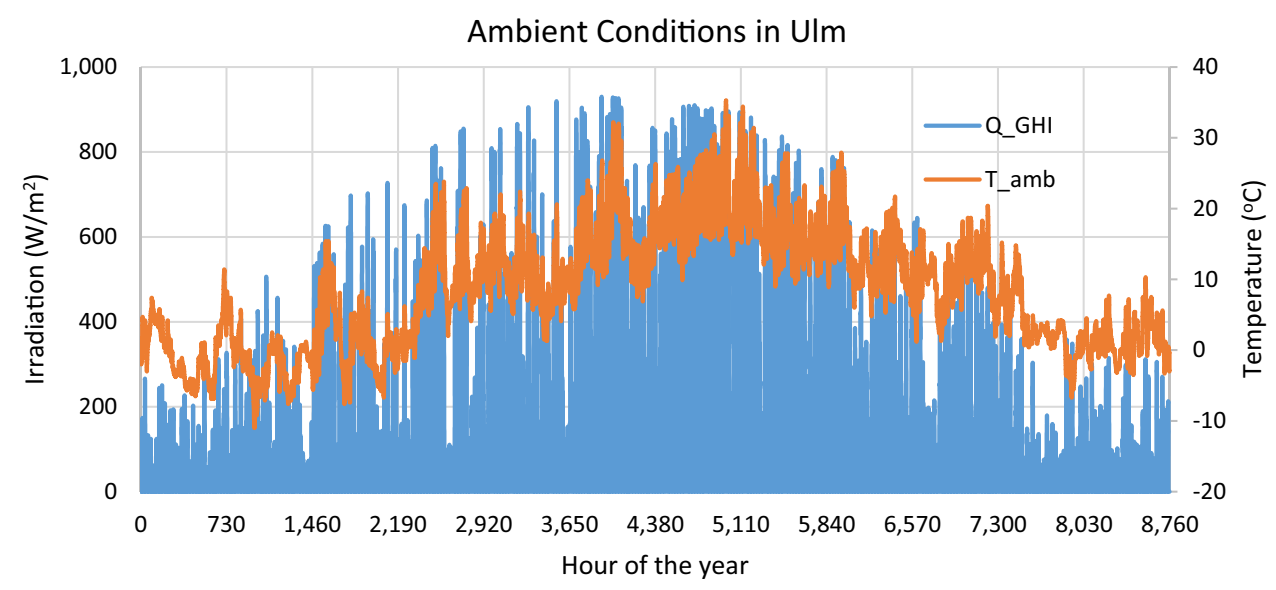


demand). The $50 \%$ solar fraction can be reached by solar thermal and/or photovoltaic system. The 50\% solar fraction should be with respect to a reference system without solar thermal or photovoltaics. The primary energy normally should not reach more than $15 \mathrm{kWh} / \mathrm{m}^{2}$. But exceptions can be given to systems which have an auxiliary heater fed with fossil fuels where $30 \mathrm{kWh} / \mathrm{m}^{2}$ primary energy is allowed but this will be mentioned in the certificate. For the transmission heat loss, it should be at least $85 \%$ better than an EnEV [26] building code standard at the time of building the house. If it is renovated house then it should not exceed more than $115 \%$ of EnEV standard. One of the common practices is not to install heat recovery forced ventilation units in such Sonnenhaus buildings.

\section{Passive house}

One of the important criteria for a passive house is that the primary energy demand should not be more than $15 \mathrm{kWh} /$ $\mathrm{m}^{2}$. The $U$ value of the three glazed windows should be under $0.8 \mathrm{~W} / \mathrm{m}^{2} \mathrm{~K}$ and $g$ value around $50 \%$. As a rule of thumb for the combined $U$ and $g$ value verification, for a cool weather (middle Europe), the value of solar heat gain coefficient which is $U_{\mathrm{g}}-g^{*} 1.6$, where $U_{\mathrm{g}}$ is the $U$ value of glazing and $g$ is $g$ value of the window, should be less than or equal to zero. The total external envelope $U$ values should be less than $0.15 \mathrm{~W} / \mathrm{m}^{2} \mathrm{~K}$. The forced ventilation should be designed such that at least $75 \%$ of the heat is recovered (effectiveness). The ventilation at $50 \mathrm{~Pa}$ pressure difference should be 0.6 changes per hour [27].

\section{WSchV095}

Wärmeschutzverordnung (Thermal Insulation Ordinance) 1995 is a simple building standard where the basic necessity is that the house should be heated up to $19{ }^{\circ} \mathrm{C}$ with the
$U$ values of the windows (at least double-glazed) along the frame and leaks not reaching more than $1 \mathrm{~W} / \mathrm{m}^{2} \mathrm{~K}$; door and roof windows not exceeding $0.7 \mathrm{~W} / \mathrm{m}^{2} \mathrm{~K}$. But as an exception in Appendix 1, Sect. 7 under Table 2 of [28], it is mentioned that if average equivalent heat transfer coefficient $\left(k_{m, \text { Feq }}\right)$ is less than 0.7, then it is fine. The value $k_{\mathrm{eq}, F}=k_{F}-g * S_{F}$ in $\mathrm{W} /\left(\mathrm{m}^{2} \mathrm{~K}\right)$ where $S_{F}$ (solar heat gain coefficient) is taken as $1.65 \mathrm{~W} / \mathrm{m}^{2}$ and $k_{F}$ is determined heat transfer coefficient. The outer walls should not transmit more than $0.50 \mathrm{~W} / \mathrm{m}^{2} \mathrm{~K}$. The roof should be insulated such that the $U$ value is less than $0.22 \mathrm{~W} / \mathrm{m}^{2} \mathrm{~K}$ while the internal walls, ceilings, cellars, ground and walls to unheated rooms losing heat less than $0.35 \mathrm{~W} / \mathrm{m}^{2} \mathrm{~K}$ [28].

As shown in Table 1, the windows of the passive house have a $g$ value 0.45 which is less than the recommended 0.5 , but since it satisfied the rule of thumb with $U$ and $g$ values, the $g$ value was parametrized. 1.73 as the $U$ value for WSchVO95, is also according to the exception in the norms. The $U$ and $g$ values of all buildings except WSChVO95 are similar while passive house being the most heat efficient. The walls, ground and roof are also in the similar pattern. The ventilation and infiltration was calculated according to DIN 18599. For the passive house, the same ventilation and infiltration parameters as the KfW55 satisfied the requirements of passive house standards and hence same was withheld. For WSchVO95, even though DIN 18599 was not in practice at this time, still the same standard was used as simplification for simulation. The infiltration in Sonnenhaus is a double that of KfW55 and for WSchVO95, the infiltration is too huge that it itself ventilates the house and hence the ventilation is lower than the newer houses. For passive house, it is necessary that the house is well insulated and requires less primary energy, irrespective a renewable generation plant is installed onsite. But the scenario is different for a Sonnenhaus standard where the main aim is to cover at least $50 \%$ by solar energy and the other factors such as walls, insulation and infiltration are of less importance. KfW55 is a compromise between all of it which moves

Table 1 Building parameters overview of the four different standard building models

\begin{tabular}{|c|c|c|c|c|c|}
\hline & Sonnenhaus & Passive house & KfW55 & WSchVO95 & \\
\hline \multicolumn{6}{|l|}{$U$ value } \\
\hline Outer wall & 0.179 & 0.122 & 0.16 & 0.6 & \\
\hline Roof & 0.15 & 0.121 & 0.153 & 0.275 & \\
\hline Internal wall & 0.343 & 2.58 & 0.343 & 1.96 & \\
\hline Windows & $\begin{array}{l}U \text { value } \\
0.7\end{array}$ & $\begin{array}{l}U \text { value } \\
0.59\end{array}$ & $\begin{array}{l}U \text { value } \\
0.68\end{array}$ & $\begin{array}{l}U \text { value } \\
1.73\end{array}$ & $\begin{array}{l}g \text { value } \\
0.705\end{array}$ \\
\hline Ground & 0.151 & 0.139 & 0.185 & 0.448 & \\
\hline Ceiling & 0.348 & 1.65 & 0.348 & 1.65 & \\
\hline Ventilation & $0.461 / \mathrm{h}$ (no heat recovery) & $\begin{array}{l}0.431 / \mathrm{h} \text { (heat recovery } \\
\mathrm{E}=75 \%)\end{array}$ & $\begin{array}{l}0.431 / \mathrm{h} \text { (heat recovery } \\
\mathrm{E}=75 \%)\end{array}$ & $\begin{array}{l}0.381 / \mathrm{h} \text { (no heat } \\
\text { recovery) }\end{array}$ & \\
\hline Infiltration & 0.14 & 0.07 & 0.07 & 0.42 & \\
\hline Primary energy & $<30 \mathrm{kWh} / \mathrm{m}^{2}$ & $<15 \mathrm{kWh} / \mathrm{m}^{2}$ & - & - & \\
\hline
\end{tabular}


buildings towards affordable sustainability such as making use of heat-recovered ventilations.

When the building is seen more into detail, the way they respond is so different and this was the main reason these building standards were chosen. The oldest WSchVO95 building with their high infiltration and weakly insulated walls have a very high energy consuming building and is very reluctant to seasonal changes and the sun on winter days has less effect and the thermal mass used heat storage is not that pronounced. But on the other hand, the passive house is very sensitive to any kind of internal energy gains and solar gains via windows such that even in winter some hours of sun will be enough to withheld some hours without heating.

\section{Model description in TRNSYS}

\section{Thermal system}

The building as per the standards is created and properties are defined in the TRNBuild software which is a part of the TRNSYS software, where the other energy system components are defined and the simulation is carried out. For such simulations with high dynamic possibilities is the software TRNSYS (Transient System Simulation Tool) [29] famous. For the degree of freedom and its module plug and play concept, it is so flexible and custom designable. Each of the component in the system is a separate block (called as 'Type') in which the parameters can be defined. In addition, each of the output and input components can be interconnected so that they can communicate with each other. In TRNSYS, there are lots of pre-developed models available which can be connected together and integrated as a system, such as in Matlab Simulink. Furthermore, new component models can be coded and created.

The simulations are carried out with the Ulm, Germany's historical weather data from 2013. The schematics of the energy system configuration is shown in Fig. 3. The solar thermal collector data for Type 539 are inputs from the datasheet of the Focus AR Collector [30]. The collector is assumed to be mounted at $55^{\circ}$ slope and facing $0^{\circ}$ south and filled with a $60 \%$ glycol Tyfocor fluid and work at the specific mass flow of $15 \mathrm{l} / \mathrm{hm}^{2}$. Type 340 model [31] is used to simulate the storage tank Sailer Hybrid Quattro [32]. The data are transferred to the model via a parameter identification done at ITW, Uni-Stuttgart and the model is fitted accordingly. As the tank is special due to its lances and heat exchanger combine lance for solar heat input, the modelling approach is complicated. More about the tank can be found at [19], where modelling approach is focussed in that previous publication. For the gas boiler, type 700 , a simple gas condensing boiler is used. There is also an electrical heater inside the tank which is used to feed-in the excess electricity from the decentralized production if the water store can take in heat, so that the self-utilization of the decentrally produced electricity is prioritized and energy fed to the grid is kept low. The internal electrical heater inside the tank is capped at $4 \mathrm{~kW}$ and the excess energy from the fuel cell and PV is being fed in the tank if the sensor temperature at 0.8 relative height is less than $80{ }^{\circ} \mathrm{C}$. With the use of Matlab calling function (Type 155), the fuel cell is modelled. BlueGen from Ceramic Fuel Cells is used [33] which is a $2 \mathrm{kWel}$ SOFC (Solid oxide fuel cell), which takes $30 \mathrm{~h}$ to start up and the fuel cell is therefore running all through the year at $1.5 \mathrm{~kW}_{\mathrm{el}}$. The thermal energy is also acquired from the cooling of the fuel cell exhaust which is fed to the storage tank. The water temperature at the tank from the lance is given to the matlab model. The requirement of the fuel cell in a SFH or selection of SOFC instead of PEM-FC (proton exchange membrane) is debatable, but in the iHEM project, it has been used and hence is used also for this study. A fresh water station for the delivery of domestic hot water (DHW) is used. The Sailer FriWasta [34] is modelled using a heat exchanger and a diverter-mixer valve combo. The hot water loads are derived from the nominal profile according to VDI 4655 and with $500 \mathrm{kWh}$ per person. The 15-min profile is then used in TRNSYS.

The building is heated with the help of floor heating in KfW55, Sonnenhaus and passive house and via radiators (Type 362) in WSchVO95. With the help of an on-off controller and a PID controller (two step), the set point for the mass flow is achieved which considers the room temperature and the desired room temperature. The heating system works such that the room is $20^{\circ} \mathrm{C}$ and during night a desired room temperature of $16^{\circ} \mathrm{C}$ during 22:00-6:00 in the nights. There assumed to be four persons living in the house and the gains are such that there is at least one person in the house and the electrical gains are also taken into the account. In addition, with the help of a diverter and mixer valve, the temperature inlet to the space heating is varied and this is done in accordance to the ambient temperature. The gas boiler is controlled such that the auxiliary volume of the storage tank is kept at $50{ }^{\circ} \mathrm{C}$ in all cases except WSchVO95 where it is to be maintained at $65^{\circ} \mathrm{C}$. Moreover, the radiators at WSchVO95 building require a lot of power, and radiator is an older high temperature model, and hence the gas boiler is also sized such that this is satisfied. As mentioned in Table 1, the infiltration and ventilation systems were designed for each building. Along with that, the simulation of window opening during the summer months is achieved via increasing the infiltration when the ambient temperature goes above $26^{\circ} \mathrm{C}$. The self-shading and shading via overhangs are also taken into account in the simulation. 


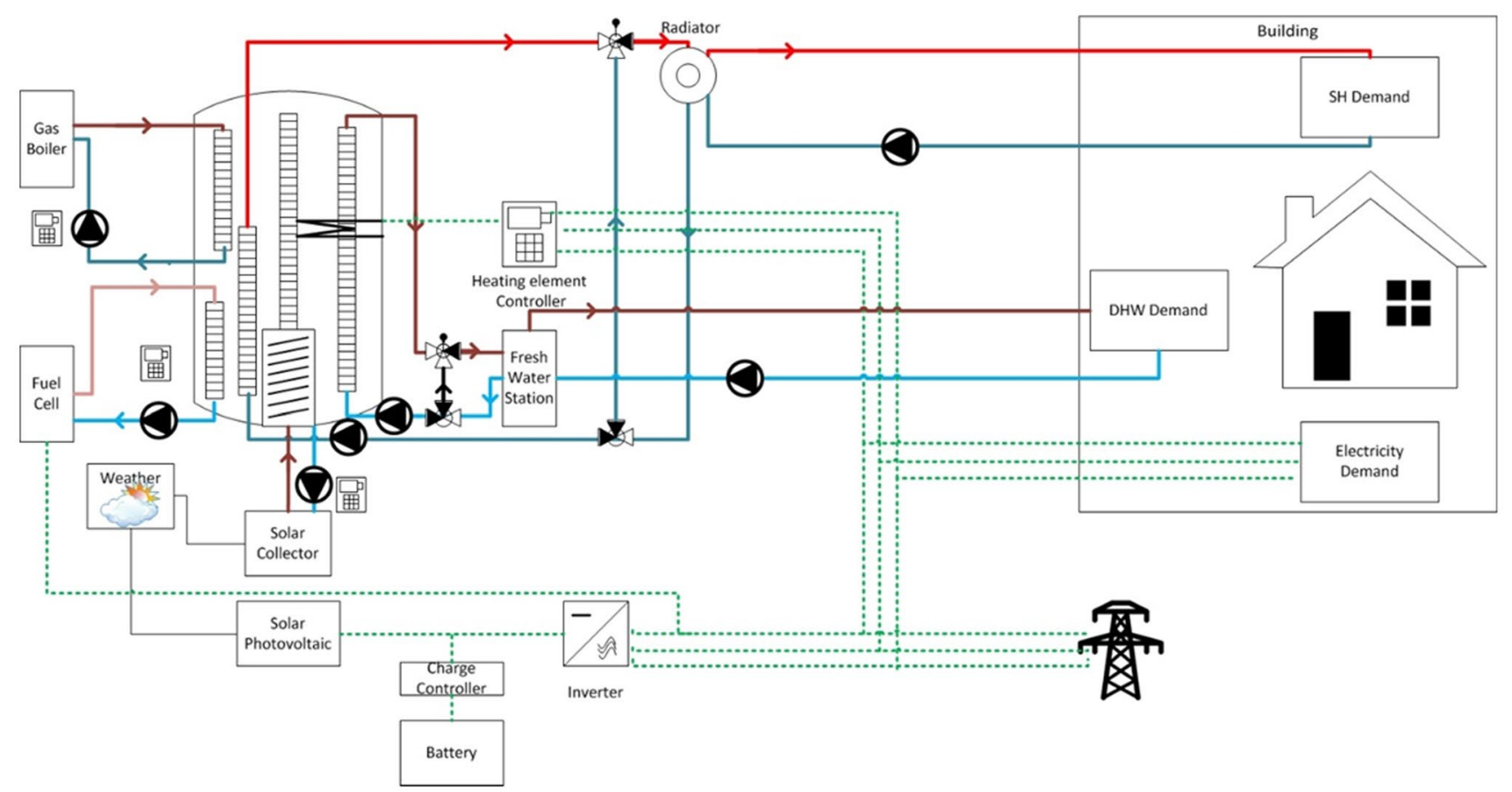

Fig. 3 Schematics of the energy system as simulated in TRNSYS

\section{Electrical system}

With the Type 155 Matlab model, the fuel cell also delivers electricity. Since the fuel cell is single phased and has a self-internal control and inverter unit, there is just directly $1.5 \mathrm{~kW}_{\mathrm{el}}$ AC power out of it. Along with that, PV (Type 94a) with a $35^{\circ}$ slope facing south is connected and Aleo Solar S19-295 [35] data is input, which will also load a battery (Type 47a), a simple lead acid model which is in turn connected to the simple inverter model (Type 48b) which along with some equations and modifications acts like a three-phase inverter model along with the charge controller integrated. The fuel cell connected on the AC side of the inverter to one of the three phases in the third phase. The inverter efficiency curve is also integrated using the polynomial equations. One simplification is that the load curve is designed from the VDI 4655 and the nominal values are converted to a 4-person household with $4140 \mathrm{kWh}$ annual consumption. One simplification was that this total one load curve was divided equally for all the three phases which is not the situation in real. In phases 1 and 2, it is clear that if there is PV production or energy available in the battery, then this is used otherwise the electricity is withdrawn from the grid. But on the phase 3 with the fuel cell connected, the energy delivered to the load is assumed to be such that if no PV production, then CHP will deliver the maximum it can to third phase load. If there is PV production and if PV produces less than $50 \%$ of the load in third phase, then CHP delivers the remaining load after PV power delivery and if $\mathrm{PV}$ production is more than $50 \%$, then CHP delivers up to $50 \%$ of the load in phase 3 . The excess power from all three phases is then utilized if possible in the heating element inside the thermal storage and the remaining is fed to the grid. One of the disadvantages of this system configuration is that the fuel cell does not charge the battery and cannot supply to the other phases and excess power is either sent to thermal store or to the grid. There are three different electrical heating elements in the real tank which can be operated by all three phases, but in simulation model, it is assumed that there is only one heating element at 0.60 relative height and is fed by all three phases up to a capped maximum of $4 \mathrm{~kW}$.

\section{Assumptions and simplifications in the model}

(1) Since the storage tank model (type 340) cannot have a lance with one port or have an open loop with 2 lances, (as the mass flow in a lance should be constant as inlet and outlet ports) there is a modification in the space load, gas boiler and DHW lances which are used for the Sailer's Hybrid Quattro and in the simulation.

(2) The fresh cold water is assumed to be $10{ }^{\circ} \mathrm{C}$ in winter and $12{ }^{\circ} \mathrm{C}$ in summer and the delivered DHW water is assumed to be $55^{\circ} \mathrm{C}$. 
(3) The pipes are not modelled in the simulation as this is just an energy simulation and the heat loss through pipes is overlooked.

(4) The glycol-water solution in the collector circuit is assumed to have a constant fluid-specific heat and density irrespective of the temperature of the solution.

(5) The solar collector flow rate is kept at a medium constant flow rate in the simulation, while in the real system, the master controller controls the mass flow rate

(6) The electrical load is given in three phases, but is basically derived from a single load curve according to VDI 4655 and divided equally to three phases

(7) Instead of three heating elements with three-phase supply in the real thermal store in simulation, there is only one heating element inside the store which will be powered by all three phases.

(8) Night reduction of desired room temperatures to $16{ }^{\circ} \mathrm{C}$ from the usual $20^{\circ} \mathrm{C}$ is assumed to be the case.

\section{Building simulation input parameters}

One more noteworthy thing to reiterate is that the sizing of the energy system is optimized for the base case (KfW55) and the same sizing configuration is used for other three buildings. The main criteria for sizing were high self-production but at the same time economically sensible sizing. The reason for this is to show the effect of sizing and the control system dependency on the building standard. The building KfW55 is selected as a base case because this is one of the currently most built-up single family buildings standard in Germany. The building input parameters for all the buildings along with the main TRNSYS types are mentioned in the table below. The solar thermal is first sized at $26 \mathrm{~m}^{2}$ gross collector area with $2 \mathrm{~m}^{3}$ storage tank. While $2 \mathrm{~m}^{3}$ tank was sufficient for KfW55, Sonnenhaus and Passive house but for WSchVO95 a $3.5 \mathrm{~m}^{3}$ storage is required. Along with mere $5 \mathrm{~kW}$ gas boiler and $4 \mathrm{~kW}$ heating element, the thermal loads of all buildings except WSchVO95 is easily satisfied. The gas boiler makes sure that at 0.75 relative height of the tank $\left(\mathrm{H}^{\prime}\right)$ the temperature is $55^{\circ} \mathrm{C}$ and flow rate is set at $200 \mathrm{~kg} / \mathrm{h}$ with the minimum turn down ratio 0.1 . For WSchVO95, a $30-\mathrm{kW}$ gas boiler is required and the set point has also to be increased to $70{ }^{\circ} \mathrm{C}$ and the mass flow into the gas boiler is also in accordance changed to $1200 \mathrm{~kg} / \mathrm{h}$ and the sensor for gas boiler control in the storage should be placed at $0.6 \mathrm{H}^{\prime}$ only with which the auxiliary volume for the building heating is achieved. In addition, the available $2 \mathrm{~kW}_{\mathrm{el}}$ SOFC fuel cell feeds in a maximum of $600 \mathrm{~W}$ of thermal gains when temperature of inlet water is less than $30{ }^{\circ} \mathrm{C}$ after which the thermal gains gradually decrease and from $60{ }^{\circ} \mathrm{C}$ inlet water there are completely no thermal gains from the FC-CHP. As already mentioned, fuel cell is in operation all-round the year and takes the coldest water available in the storage tank and at $90 \mathrm{~kg} / \mathrm{h}$ cools the fuel cell exhaust for thermal gain. The FC-CHP held in the same conditions for all the building standards.

On the load side, the set point temperature for the hot water is $55{ }^{\circ} \mathrm{C}$ and takes the hottest water possible from the tank and mixes it via a diverter-mixer combo and feeds into the fresh water station with a $1500 \mathrm{~W} / \mathrm{K}$ heat transfer rate to the fresh cold water. For the space heating, there is an active floor area as floor heating in the building model for KfW55 which is $50 \mathrm{~m}^{2}$ together for both the heated zone floors. These sum up to a required minimum of $500 \mathrm{~kg} / \mathrm{h}$ and set maximum of $1000 \mathrm{~kg} / \mathrm{h}$ for the floor heating mass flow. In addition, in accordance to the ambient temperature, the inlet temperature of the space heating load varies from 25 to $38{ }^{\circ} \mathrm{C}$. As already mentioned, a night temperature reduction is set to $16{ }^{\circ} \mathrm{C}$ desired room temperature which is otherwise $20{ }^{\circ} \mathrm{C}$. For passive house and Sonnenhaus also, a floor heating is used. But for those a $100 \mathrm{~m}^{2}$ heating area with lesser flow rate of $200-700 \mathrm{~kg} / \mathrm{h}$ is required. For WSchVO95, the heating temperatures from floor heating are not enough and hence a radiator of $45 \mathrm{~kW}$ maximum power with a maximum flow rate of $1200 \mathrm{~kg} / \mathrm{h}$ with a higher inlet temperature set of $35-57^{\circ} \mathrm{C}$ is input.

As in KfW55, there is a heat recovery ventilation system which has exchange effectiveness $(E)$ of $75 \%$ at an exchange rate of 0.43 changes per hour. The ventilation and infiltration of the buildings are input according to the standards as shown in Table 2. Moreover, it is assumed to be four people living in the house, and all four spending the night, of which three people go off in the morning and slowly back in the afternoon one by one. $81 \%$ of the electrical consumption in the house is assumed to be the other thermal gains in the house. For forced ventilation and shading, the ambient temperaturedependent control opens the jalousie for shading when temperature is above $24{ }^{\circ} \mathrm{C}$ outside so that solar gains are avoided inside the buildings and windows are assumed to be opened for forced ventilation when temperature is above $26^{\circ} \mathrm{C}$.

On the electrical side, the system is same in all the buildings except that the excess electrical energy fed to the thermal store is dependent on the temperature level in the store. PV is sized for $2.9 \mathrm{~kW}_{\mathrm{p}}$ which occupies $19 \mathrm{~m}^{2}$ roof area and the parameters are input according to the data sheet of Aleo Solar S295. The suitable inverter at $3.3 \mathrm{~kW}$, the Stecagrid 3203 from Steca is input. The given inverter efficiency with respect to the power ratio from total inverter size, as shown in the datasheet, is given as a polynomial equation into the inverter model. Battery with $6.8 \mathrm{kWh}$ from BMZ (ESS 7.0) including Steca charge controller with all their properties is input from the datasheets of the respective components. The simulation time step and data files interval are all input as 15-min time step. The matlab fuel cell model is called every time step. The weather data in an hourly dataset are interpolated for 15 min data points. 


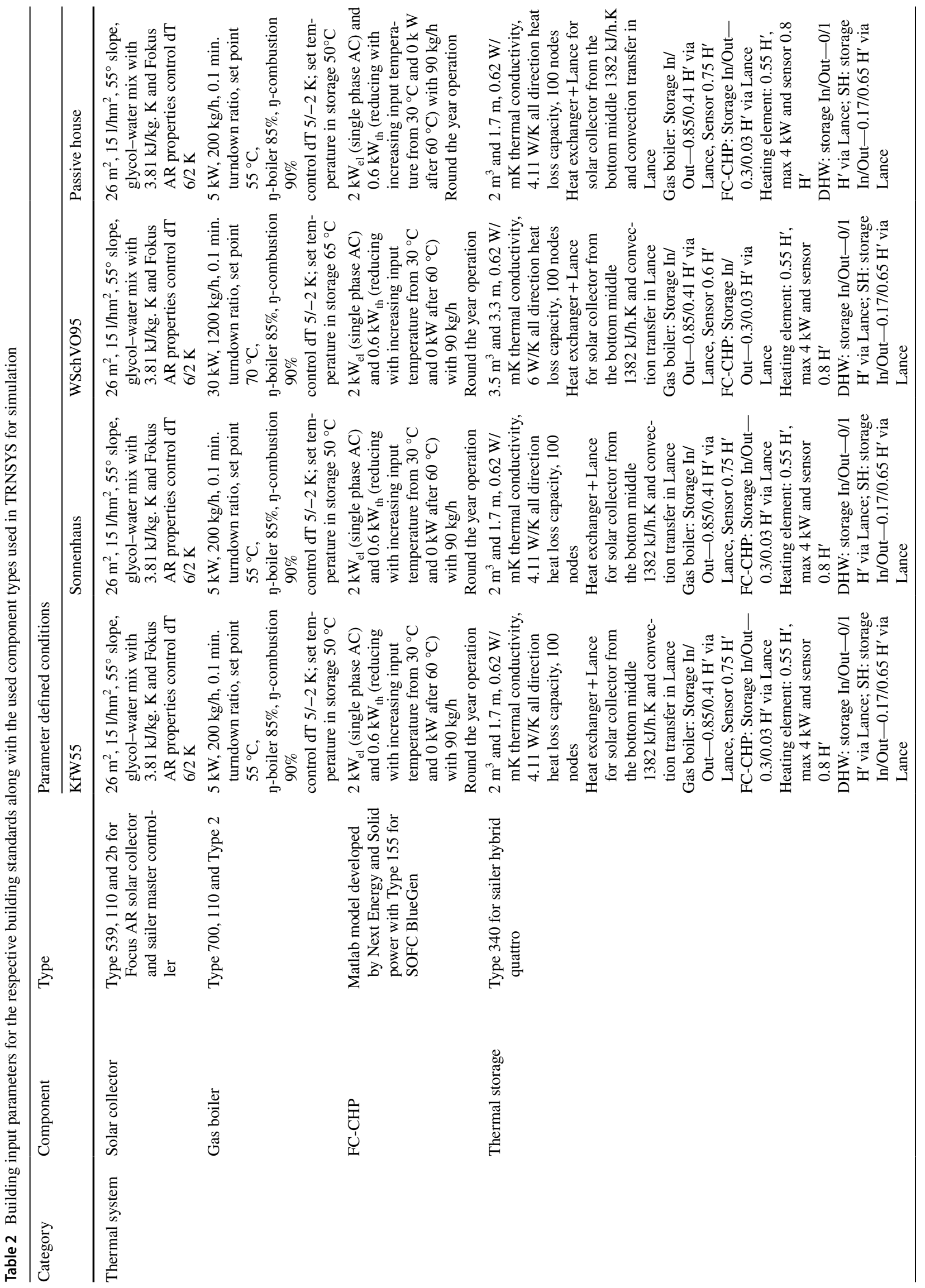




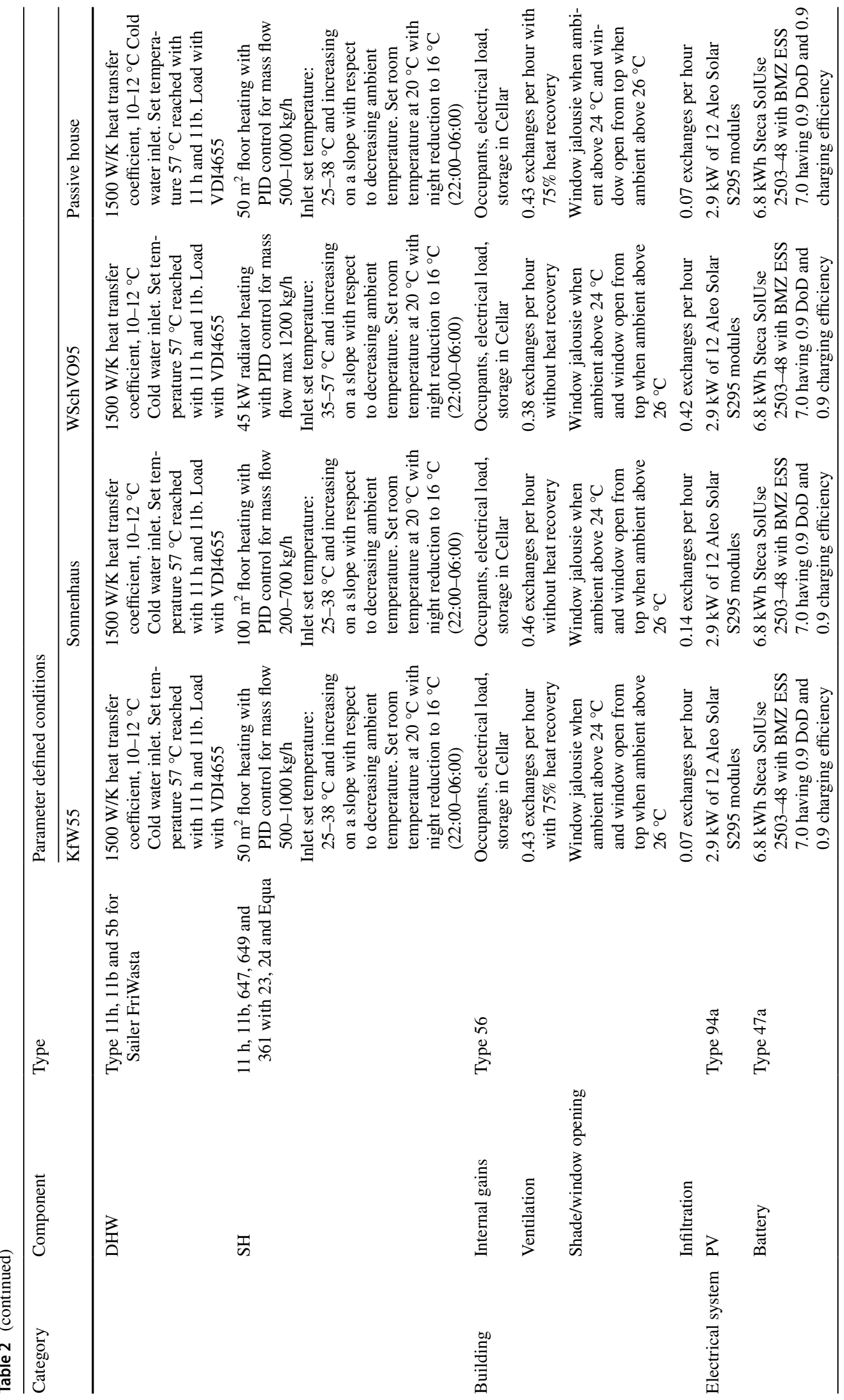




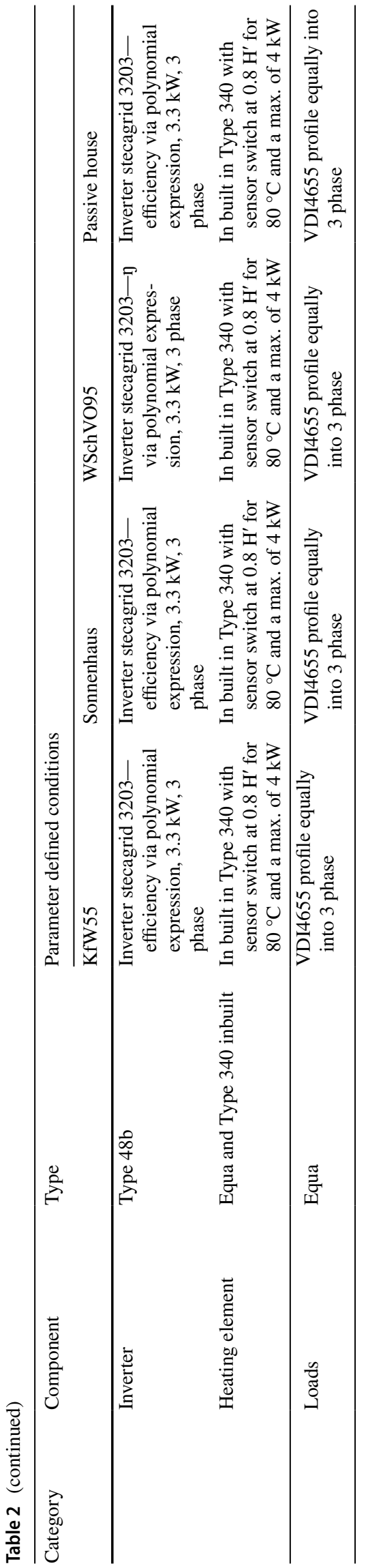

\section{Results}

\section{Base case results of KfW55 (thermal and electrical)}

The simulation for the KfW55 building was carried out with the above mentioned parameters. Figure 4 shows the thermal energy system results. In Fig. 4 on the left, the monthly energy production or consumption is shown in the form of bar diagram. The respective month's solar fraction and heating element contribution is also shown as a line graph. The same parameters such as collector production, gas boiler input, DHW demand, SH demand and power to heat production are shown in yearly energy values in the first graph on the right (Energy/a). Then in the right extreme bottom, the specific collection production per unit area per annum $\left(E_{\text {Coll-spec }}\right)$ is plotted and the total Energy fraction from each system (EF/a) separated in terms of gas boiler, power to heat and solar collector heat shown in the right top plot.

The solar collector and excess decentralized electricity contributes to almost $87 \%$ of the total load requirement for space heating $(\mathrm{SH})$ and domestic hot water (DHW). The solar thermal fraction alone is $44 \%$. It also shows that the fuel cell CHP produced energy as power-to-heat contributes a lot in the winter months which has the gas boiler requirement in check. As a result, a 5-kW gas boiler is enough for this KfW55 house. At $26 \mathrm{~m}^{2}$ collector area, it seems to be quite oversized with specific collector production less than $200 \mathrm{kWh} / \mathrm{m}^{2}$ and this might be due to the utilization of excess electricity in the transition seasons and partly also due to a small tank. It is also to be noted that even in peak winter, the maximum power required by space heating is $7 \mathrm{~kW}$ and less than $1500 \mathrm{kWh}$ in January. It is to be noted that the heat recovery enabled forced ventilation plays an important role and hence an annual requirement for space heating is $6542 \mathrm{kWh}$ and for DHW is $4316 \mathrm{kWh}$. Another $2014 \mathrm{kWh}$ is being delivered from the fuel cell CHP but, since this is a very low grade heat, the use of it is very limited. In contrary, another $1152 \mathrm{kWh}$ of $55^{\circ} \mathrm{C}$ is being delivered by gas boiler for the demand of the thermal loads.

On the other hand, for the electrical demand (as shown in Fig. 5), there is a lot of surplus energy, especially due to the fuel cell CHP production which cannot charge the battery. Thus, a $2.9-\mathrm{kW}_{\mathrm{p}} \mathrm{PV}$ array can only deliver $22 \%$ of the total decentrally produced electricity while the CHP produces a whopping 13,140 kWh. As shown in Fig. 4, due to the excess production by fuel cell which can also not be stored in the battery, $8755 \mathrm{kWh}$ is fed to the grid, which is $53 \%$ of the decentrally produced energy. There is also another $27 \%$ fed to the thermal store and only the other $20 \%$ is being demanded by the load. $1015 \mathrm{kWh}$ of extra energy has to be consumed from the grid while there is not enough energy in phase 3 to satisfy peak demands; and in phase 1 and 2 where the battery is 


\section{Energy Parameters from KfW55 SFH}

based on the historical weather data for UIm 2013
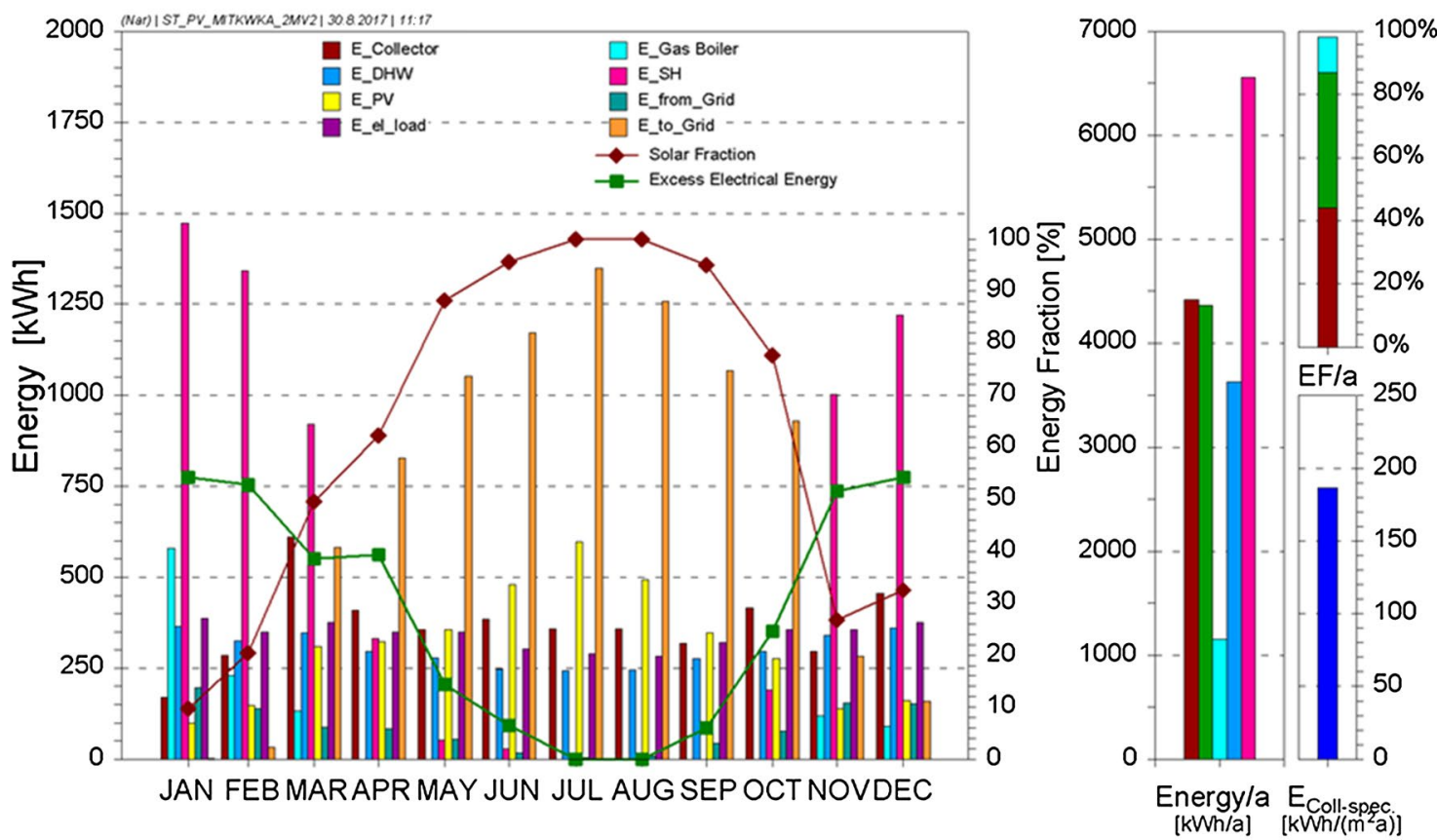

Fig. 4 Thermal system results of KfW55 building

empty and no PV production. But in one way, it makes things good as the excess fuel cell electricity provides the thermal energy to the store largely during winter and transition seasons, thus reducing the necessity of the gas boiler. Of the $3267 \mathrm{kWh}$ supplied to the loads, $1104 \mathrm{kWh}$ are delivered by the battery, which makes 225 full cycles. $80 \%$ of the electrical loads are thus satisfied with self-production. Unfortunately, only $6 \%$ of the produced CHP's electricity (27\% of the loads are met by CHP's electricity) is being able to be delivered to the electrical loads. Of the remaining, $48 \%$ is being delivered either directly by PV or through the battery storage.

\section{Case without fuel cell}

To understand the system without fuel cell CHP, a reference system without fuel cell was simulated for KfW55. The results are shown in Fig. 6. Due to this, the major change in the thermal side is that the excess electrical energy is almost nil. Thus, demanding a lot of auxiliary power via gas boiler for satisfying the loads during winter. Due to this, annual gas boiler requirement shoots up to $6685 \mathrm{kWh}$ which is $72 \%$ annual thermal demand. Another $53 \%$ of the input energy is then provided by the solar thermal collectors. With an increased storage volume of $4 \mathrm{~m}^{3}$, a solar fraction of $62 \%$ can be achieved. If it is looked more into detail, the collector output has increased due to the absence of low grade heat from the fuel cell CHP. As a positive, the solar thermal feeds the demands $100 \%$ during the 5 summer months. On the electrical side, there are more variations as all three phases are almost the same until the supply to the loads. As a result, the $3727 \mathrm{kWh}$ of PV production is the only self-production and only $2180 \mathrm{kWh}(53 \%)$ of the total $4098 \mathrm{kWh}$ electrical loads are supplied by the system. The other $1918 \mathrm{kWh}$ is taken from the grid. The excess $738 \mathrm{kWh}$ in the summer months is fed to the grid and a mere $67 \mathrm{kWh}$ is the only electrical energy fed to the thermal storage. As expected, also the battery makes 20 more full cycles (245) per annum. $58 \%$ of the produced PV energy (decentralized electricity production) is then being able to be self-utilized.

\section{Sonnenhaus results}

With the same system and the Sonnenhaus building construction, the heating demand of the building increases to $11,252 \mathrm{kWh} /$ annum, which is $75 \%$ higher heating energy demand than that of KfW55. As a result of the increased energy demand, the flowrate of the floor heating has to be changed to a maximum of $700 \mathrm{~kg} / \mathrm{h}$ and a minimum of $200 \mathrm{~kg} / \mathrm{h}$ (when switched on). The minimum and maximum set temperature remains the same at $25-38{ }^{\circ} \mathrm{C}$, while the maximum power required by the floor heating is $7.2 \mathrm{~kW}$. Even though there is an increased amount of heating 


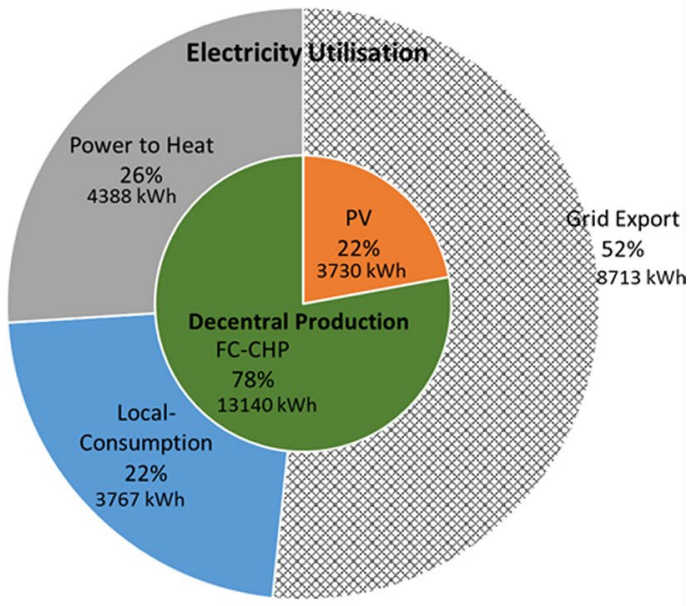

\begin{tabular}{|c|c|c|}
\hline with CHP & System Indicators & $\begin{array}{l}\text { without } \\
\text { CHP }\end{array}$ \\
\hline $12.83 \%$ & $\begin{array}{l}\text { Direct utilisation fraction of } \\
\text { decentral production }\end{array}$ & $32 \%$ \\
\hline $52.82 \%$ & $\begin{array}{l}\text { Demand covered directly using } \\
\text { decentral system }\end{array}$ & $28.8 \%$ \\
\hline $11.67 \%$ & $\begin{array}{l}\text { Direct PV energy consumed of } \\
\text { decentral production }\end{array}$ & $58.5 \%$ \\
\hline $48.01 \%$ & $\begin{array}{l}\mathrm{PV}+\text { Battery fraction of } \\
\text { decentral production }\end{array}$ & $53.2 \%$ \\
\hline $42.84 \%$ & $\begin{array}{l}\text { Power to Heat Consumption } \\
\text { Fraction }\end{array}$ & $0.76 \%$ \\
\hline $90.95 \%$ & $\begin{array}{l}\text { Maximum consumption coverage } \\
\text { using PV }\end{array}$ & $90.95 \%$ \\
\hline $44.11 \%$ & Solar Fraction (Thermal) & $53.98 \%$ \\
\hline $6.61 \%$ & $\begin{array}{l}\text { Direct FC-CHP utilisation of } \\
\text { decentral production }\end{array}$ & - \\
\hline $27.2 \%$ & $\begin{array}{l}\text { Direct FC-CHP utilisation of } \\
\text { electrical demand }\end{array}$ & - \\
\hline $62.71 \%$ & $\begin{array}{l}\text { Direct FC-CHP utilisation of } \\
\text { thermal demand }\end{array}$ & - \\
\hline $6570 \mathrm{~h}$ & Capacity FC-CHP & - \\
\hline 226 & Battery full cycle equivalent & 244 \\
\hline $19 \%$ & $\begin{array}{l}\text { Self-utilisation of decentral } \\
\text { production }\end{array}$ & $64 \%$ \\
\hline $80 \%$ & $\begin{array}{l}\text { Demand covered by decentral } \\
\text { system }\end{array}$ & $58 \%$ \\
\hline
\end{tabular}

Fig. 5 Electrical system results of KfW55 building. a Top left: results with FC-CHP. b Bottom left: results without FC-CHP. c Right: key system indicators of the KfW55 electrical system with and without FC-CHP

demand, the thermal solar fraction is 38\%, a little less than that of KfW55. Moreover, the power-to-heat fraction reduces down to $36 \%$ and hence the gas boiler fraction increases to 22\%. As shown in Fig. 7, the solar thermal collector production is increased to $5675 \mathrm{kWh}$ from $4500 \mathrm{kWh}$ in KfW55 and the main reason for this is the transition season where the sun is shining and the building is still requiring space heating. In terms of energy utilization this is bad but in terms of utilization of the solar collector, the Sonnenhaus has the upper hand. In addition, in the same way, the excess electricity fed to the thermal store is higher in terms of energy values but as the demand fraction, they are smaller in numbers due to the increased demand. Notably, the gas boiler energy demand increases with up to a $1125 \mathrm{kWh}$ required in January with $3263 \mathrm{kWh} /$ annum being delivered by the gas boiler, which is almost three times that of the KfW55's gas boiler demand. In the electrical system, all the component sizes are the same while the same load profile is used. But what changes is how the excess electrical energy is used and whether it goes to the thermal store or to the grid. The amount of electricity utilized is the same at $3267 \mathrm{kWh}$, but the amount sent to the storage tank has also considerably increased to $5411 \mathrm{kWh}$ which increases its share to $32 \%$ and the remaining $45 \%$ ( $7686 \mathrm{kWh}$ ) is fed to the grid. 


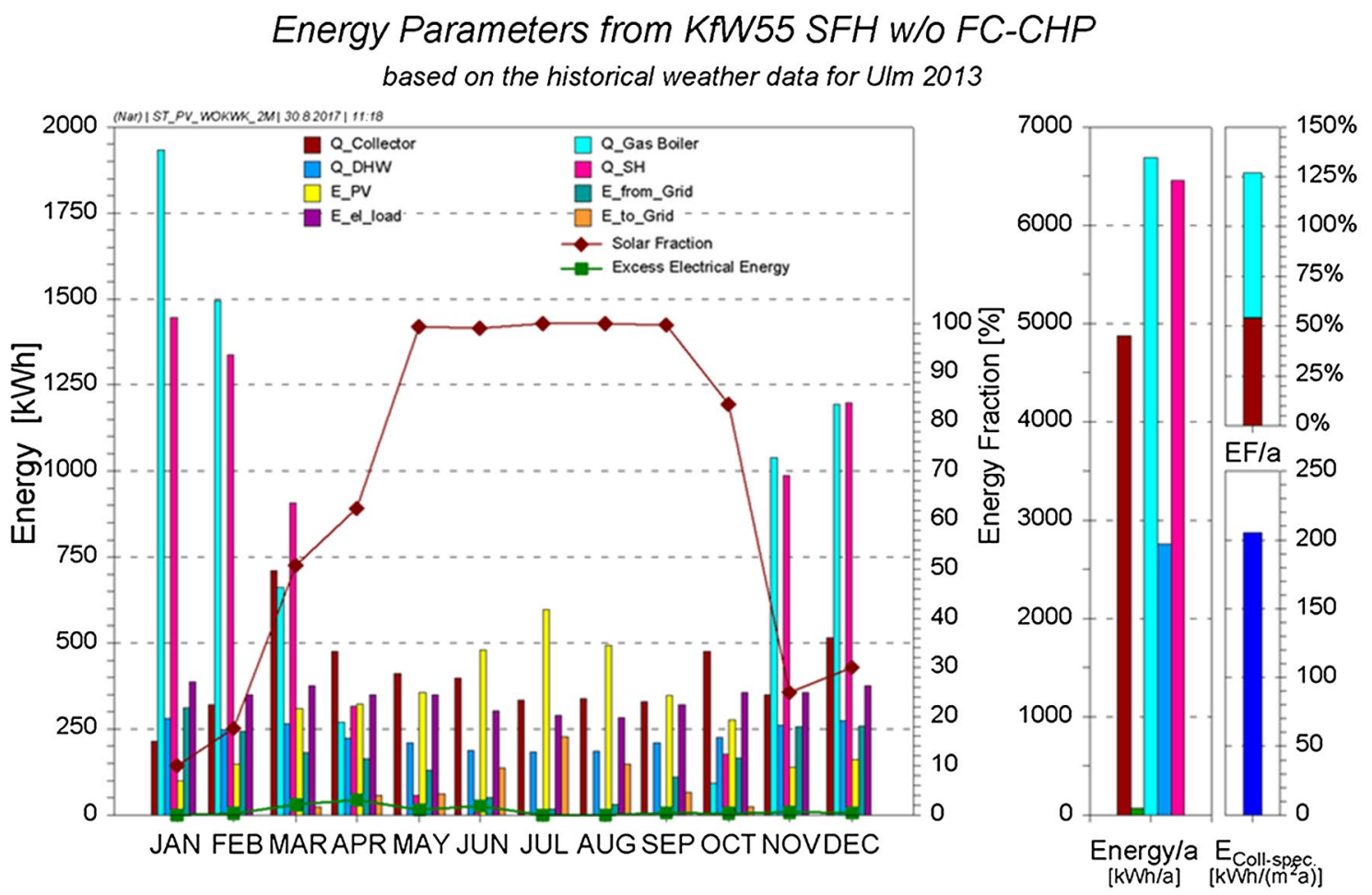

Fig. 6 Thermal system results of KfW55 building without fuel cell CHP

\section{Energy Parameters from Sonnenhaus SFH}

based on the historical weather data for UIm 2013

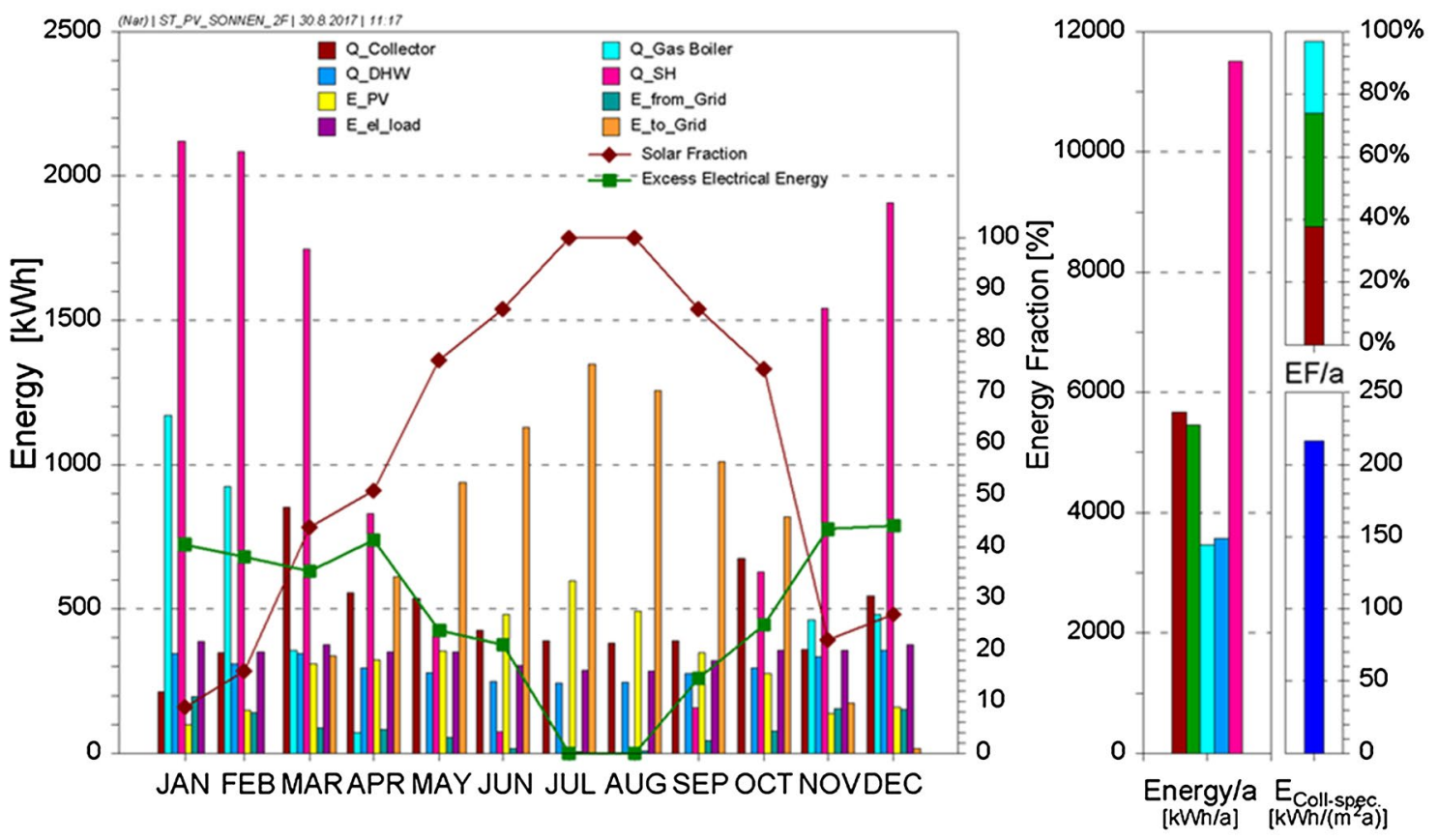

Fig. 7 Thermal system results of Sonnenhaus building 
Going back to satisfying the Sonnenhaus requirements, the $50 \%$ solar fraction can be reached by either utilizing the energy produced using solar thermal collectors or the PV. This should be viable with the current specifications but if a $50 \%$ solar fraction is to be achieved only by solar ther$\mathrm{mal}$, then the storage tank volume alone increased to $3.5 \mathrm{~m}^{3}$ from $2 \mathrm{~m}^{3}$ will achieve the $50 \%$ solar thermal fraction. In the graph on the left, it can be seen that the DHW demand (in blue) is almost constant all through the year with a small amplitude increase in the winter. But the SH demand in pink is non-uniform with the months of Dec, Jan and Feb having the highest demands. Therefore, to satisfy the demand, the gas boiler (light blue) has to be switched on but when the solar radiation is enough from the transition seasons, the requirement of the gas boiler is less while the solar collector (in brown) and the excess electrical energy (green and as line graph in percent) contribute. In addition, the PV production along with electrical demand, grid import and export is plotted in the graph.

One of the common practices in Sonnenhaus is not using a heat recovery forced ventilation system as this is not part of the requirements of the Sonnenhaus institute for certifying the building. But the Sonnenhaus building with a heat recovery ventilation system same as that of KfW55 will lead to a mere $5537 \mathrm{kWh}$ of space heating demand per annum, which is less than $50 \%$ of the current SH demand and in fact a $1000 \mathrm{kWh} /$ annum less than that of KfW55. In theory, the building in terms of Sonnenhaus requirements are much more efficient than that of KfW55 but one weak point is the ventilation system. With such a change in the requirements demanded by the Sonnenhaus institute, the building can function lot more efficient. Of course there is electricity being consumed by the forced ventilation and the opinion about it is divided, but using forced ventilation is definitely an energy efficient method. Above all, in terms of the capital and maintenance cost required to be invested in the system, it will definitely be lower if less solar collectors have to be installed with a smaller tank and less auxiliary energy is required by the system.

\section{Passive house results}

With the same building geometry, the results of a Passive house are quite astonishing. The $\mathrm{SH}$ demand goes down to $3182 \mathrm{kWh}$ which is half of KfW55's demand. In addition, the peak SH demand is $6.25 \mathrm{~kW}$ during the peak winter day when temperature is below $-15^{\circ} \mathrm{C}$. The floor heating characteristics are almost the same as of a KfW55. The gas boiler was also good enough in the same configuration as KfW55. Even though the solar thermal was quite oversized, the same number of collectors are used in the simulation so that the comparison is much meaningful. Alike KfW55, passive house also has the heat recovery ventilation. For such a system, the solar thermal fraction is $61.4 \%$. With an excess energy fraction of $40 \%$, more than a $100 \%$ of the thermal demand is autonomously produced. A remaining $1.2 \%, 78 \mathrm{kWh}$ is the only requirement from the gas boiler, and this also only during the first few days of the simulation in January where the steady state of the simulation is not yet reached. Even though excess energy fraction is $40 \%$, it is just $2716 \mathrm{kWh}$ and so the remaining excess electrical energy, $10,330 \mathrm{kWh}$ is being fed to the grid. Out of the $13,000 \mathrm{kWh}$ produced by FC-CHP, only $1080 \mathrm{kWh}$ is fed into the thermal storage as excess electrical energy. Therefore, for a passive house, even a fuel cell CHP is basically not necessary. Instead some more PV modules and a battery unit will make more sense. Probably a heat pump or a PEMFC CHP will be more effective as this can be controlled such that the production is done only when the demand is required to be met from an auxiliary device. Apart from this, the electrical side of the system is same as the base case. It is to be also noticed from Fig. 8 that the specific collector production is reduced and this is due to the reduced heat demand. In fact, the DHW load is higher per annum than the SH load.

\section{WSchV095 results}

When the same system is simulated for the same house in accordance to Wärmeschutzverordnung 1995 (heat protection rule 1995), the results are quite opposite. Since this is an old house scenario with a higher $U$ value of the building, the losses are higher and the radiators present in such houses require higher temperature operation. The $\mathrm{SH}$ demand is $26,700 \mathrm{kWh}$ which is four times the KfW55 base case scenario. Thus, the peak SH power demand rises up to $10.8 \mathrm{kWh}$. To satisfy such a heating demand, the gas boiler is designed at a capacity of $30 \mathrm{~kW}$ and the controller maintains the $0.65 \mathrm{H}^{\prime}$ at $65^{\circ} \mathrm{C}$ and the boiler produces hot water at $70{ }^{\circ} \mathrm{C}$. This is due to the fact that the space heating loop has a mass flow of $200-1200 \mathrm{~kg} / \mathrm{h}$ and the temperature of the hot water sent to the radiators has to be in the range of $35-57^{\circ} \mathrm{C}$ depending on how cold the ambient temperature is. Different in WSchVO95 is that the radiator model (Type 362 ) is used to simulate the $\mathrm{SH}$ demand. $45 \mathrm{~kW}$ radiator with $70 \%$ radiative fraction is used where radiator exponent is 1.3 and a thermal capacitance inside the radiator is assumed to be $200 \mathrm{~kJ} / \mathrm{K}$. The solar fraction dropped down from the base case to $20.7 \%$ where the solar collector annual production is $6600 \mathrm{kWh}$ ( $22 \%$ of the thermal energy demand). The remaining $62 \%$ should be provided by the gas boiler. Due to increased demand and under sizing of the system, solar collectors produce more energy. $6500 \mathrm{kWh}$ of electrical energy has to be fed into the grid. From the results shown in Fig. 9, it can be seen that $100 \%$ solar fraction is reached only during the months of July and August. Almost $75 \%$ of the space load is being delivered by gas boiler and the most part of the 


\section{Energy Parameters from Passivhaus SFH}

based on the historical weather data for UIm 2013

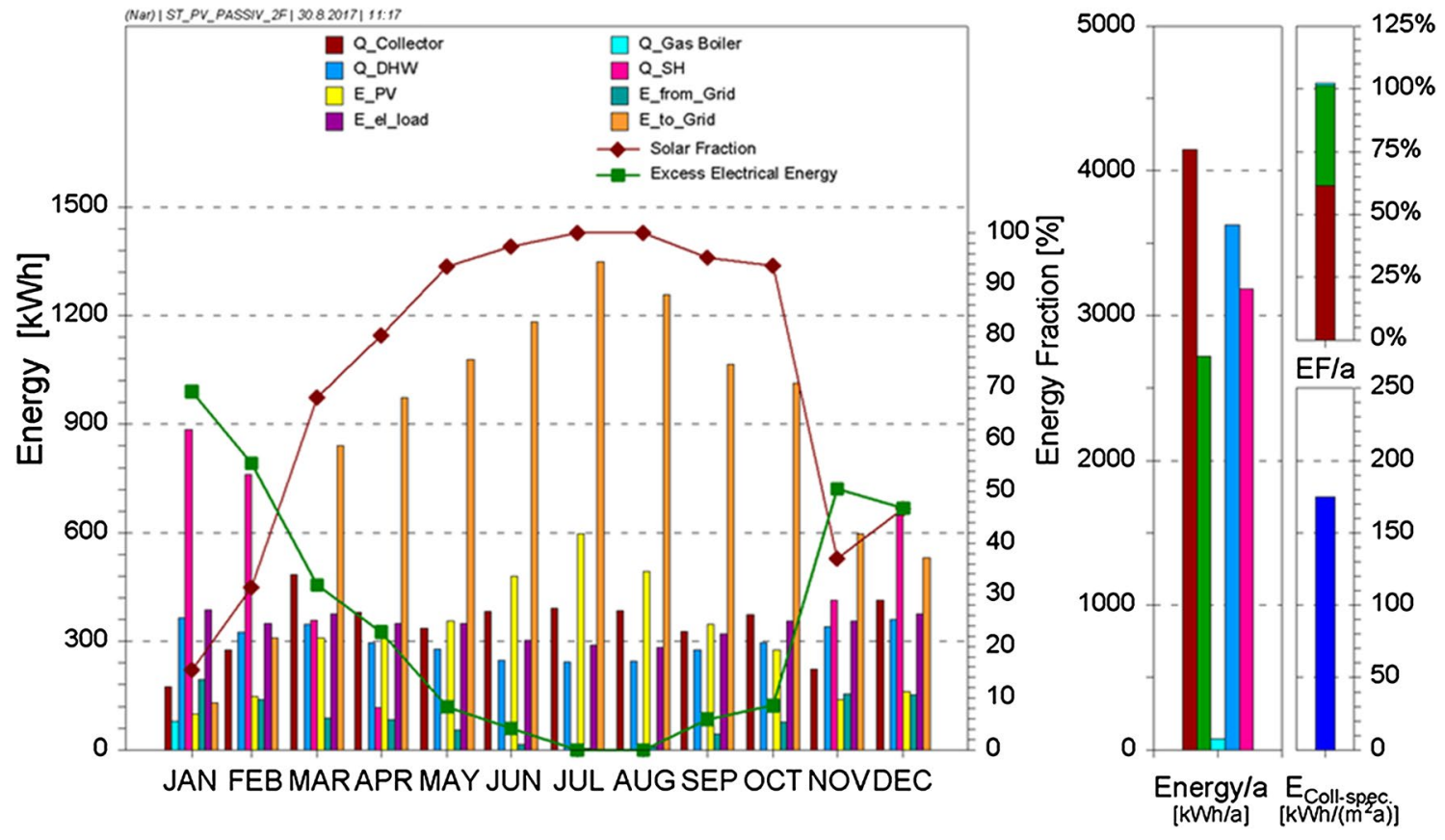

Fig. 8 Thermal system results of passive house building

\section{Energy Parameters from WSchVO95 SFH}

based on the historical weather data for UIm 2013
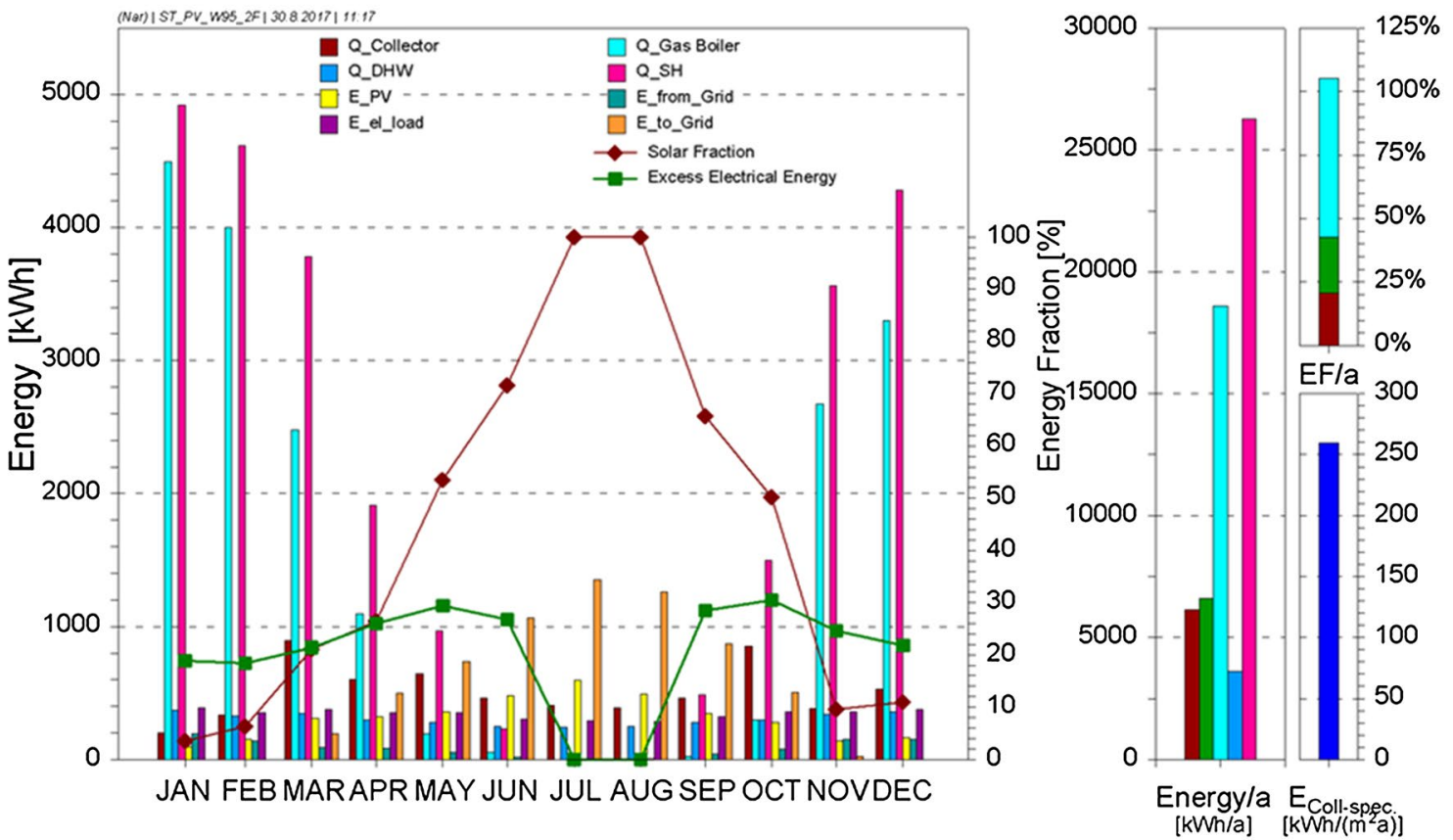

Fig. 9 Thermal system results of WSchVO95 building 
remaining space load is satisfied by the excess power from the fuel cell CHP.

\section{Discussion}

Even though the sizing of the system is kept same in this case study, the parameters or the control logic have to be fitted with each of the building type. Especially, the auxiliary production units have to be designed according to the space heating demand. Thus, the importance of buildings prove worthy in an energy system design. When the system size also has to be optimized, the controller has to be accordingly improved and this becomes tricky with every other household. Therefore, comes the necessity to use simulations in the design phase and also energy certifications are made as a requirement for each household in most of the countries. But these are done only to know the building demands. It is more important to optimize the space heating demands according to the necessity and utilization intelligently.

When the building responses are closely looked into, it could be seen that the control logic is not sufficient enough. Above in Fig. 10, a winter week's heating demands of the house is analyzed in detail. On the first graph, the temperature and the global horizontal irradiation are plotted. The temperatures go up to $-15{ }^{\circ} \mathrm{C}$ on this
Fig. 10 A winter week's simulation results showing the building demand responses for each standard
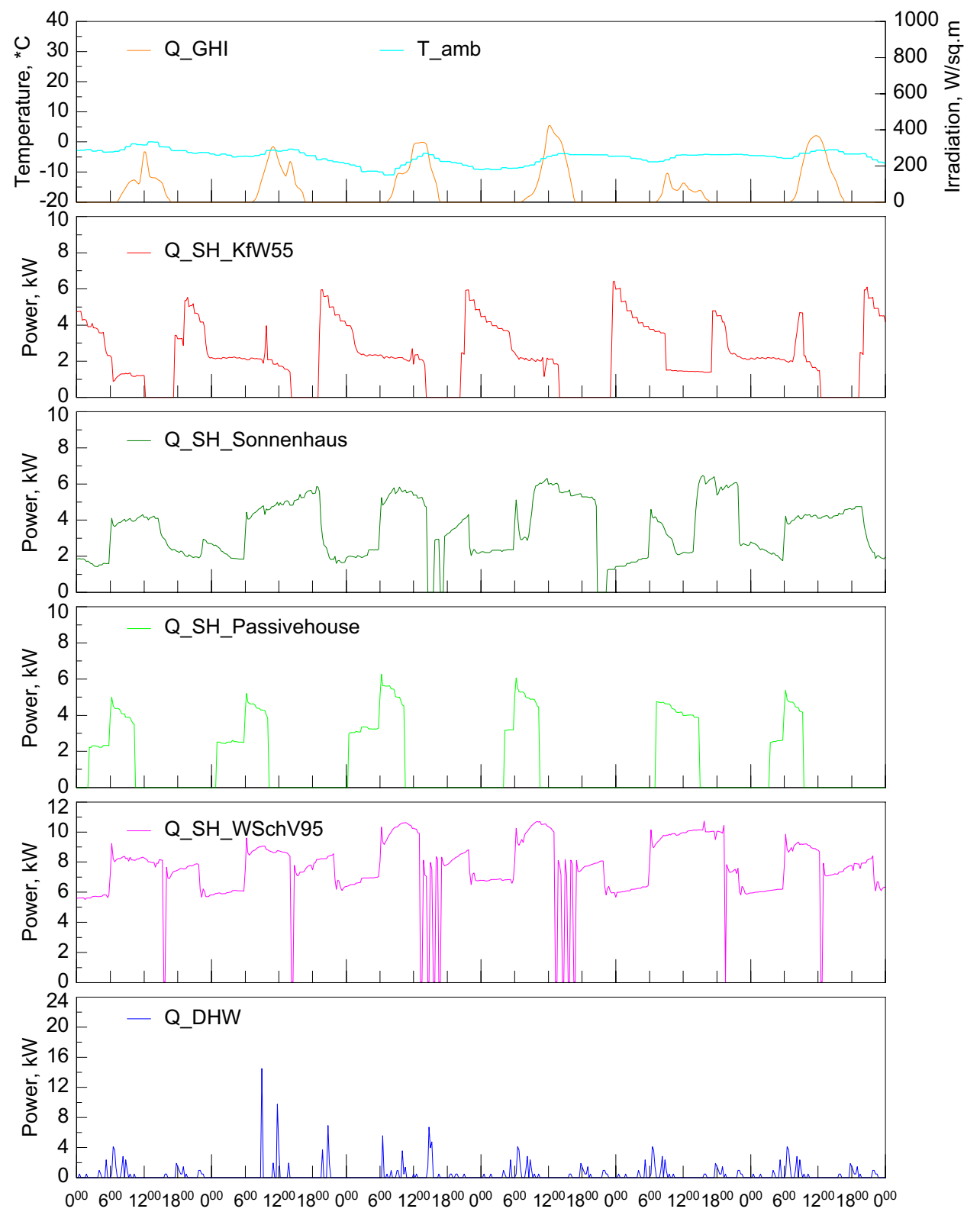

Fr,8.Feb Sa,9.Feb Su,10.Feb Mo,11.Feb Tu,12.Feb We,13.Feb Th,14.Feb 
week and the solar gains are low. And on such a day as expected in the KfW55 house the heating is on almost all the time during the day. By 12:00 pm when there was sun with just up to $400 \mathrm{~W} / \mathrm{m}^{2}$ during the day, the house got some heat through which was sufficient for the SH to be switched off. But on next day where there was almost no irradiation, the heating had to be switched on with $2 \mathrm{~kW}$ power. In the Sonnenhaus, the effect of the solar radiation is not that much while the heat lost through walls are higher and hence the heating system is not uniform. There are also some hystereses on 10 Feb. The building seems to be heated up at the beginning and then compensated by reducing the control back after which again increased. An almost perfect heating can be seen in the passive house where the heating is maximum switched on only for maximum six hour a day in winter. But due to the control logic, it should be noted that the building heats-up up to ca. $5 \mathrm{~kW}$ power which for this building is not required. And exact opposite to all these building responses is the WSchVO95, where there are a lot of hystereses and the heating power demand rises up to $10 \mathrm{~kW}$ including immediate switch off and on control commands.

Rather than the heating in Winter, the optimisation in transition seasons-spring and autumn (as shown in Fig. 11) are the difficult days to capitalise on. On these days, there are enough renewable energies, cold days but very good opportunities which are at the same time difficult to control. On such days for buildings like WSchVO95, the easy on-off control logic with still sophisticated PID algorithms currently in use be of no good. With $7-8 \mathrm{~kW}$ large amount of high grade heat being just circulated in the heating radiator and being returned to the tank creates hysteresis on a daily basis. And talking about the building response, the passive house needs no heating at all on such days. In addition, the Sonnenhaus and KfW55 houses accommodate the changes to an extend and use less heating energy.

In this study, it is shown how large is the difference between buildings of different standards. From the inferences obtained in this simulation, it can be seen that the building plays an important role in the design of the thermal energy system. More than the energy parameters, the reaction and approach to each building type vary. The KfW55 and passive house are quite reactive to the changes in the heating implementation. These both buildings need less time to reach the desired set point temperature, especially in a winter early morning where the set point temperature is varied from 16 to $20^{\circ} \mathrm{C}$ after the night reduction for energy savings. But in the similar situation for an old house such as WSChVO95, the heating has to be switched on quite earlier in the morning such as $4 \mathrm{am}$, if at $7 \mathrm{am}$ the building has to be at $19^{\circ} \mathrm{C}$ at least. Moreover, the inlet temperature and the mass flow have to be varied such that the desired room temperature is reached. The approach for a WSchVO95 building is that the inlet temperature has to vary in an increased slope value to reach the required room temperature along with an increased maximum mass flow so that the heat transfer rate is better. But for a passive house or KfW55, the slope of the inlet temperature algorithm has to smaller and the mass flow should be set that not lot of heat is transferred in one go which otherwise will create a hysteresis where the heating unit has to be switched on and off a lot of time. Not only the $U$ value (losses) of the building is to be taken into account, but also the $g$ value (the gains: solar and other) should be considered. For a passive house on a spring day, $3 \mathrm{~h}$ of sun in the mid-day will be more than sufficient to keep up the heat and reduce the space heating consumption for the remaining of the day. This can be seen by the distribution of the space heating demand difference between the months for each building type. In good insulated houses, it is evident that the space heating demand is $90 \%$ in the 4 winter months. And in the other months, the solar thermal fraction is already above $70 \%$, e.g., passive house.

Without the fuel cell and the excess energy being fed to the thermal storage, a 7-10\% increase in solar thermal production is experienced in all four buildings. The constant flow instead of the matched flow would create no change in the gained solar collector energy but with constant flow the achieved temperature is not always optimum which is disadvantage in the summer as there will be less usable high grade water in the storage. The pipes are also losing energy during transport and this is overlooked here and according to bad piping this could already be $10-20 \%$ of the total energy demand. In addition, the equal division of the 3-phase loads is not in reality possible but the alternative in real life is having an efficient 3 -phase inverter which balances each phase intelligently. Even with such boundary conditions and assumptions, the control logic of the system changes in accordance to the building type. One of the major issues is that all houses in the same building type, which has a different envelope, different $U$ value and a different window size might also not be able to operate efficiently with the same control logic. Moreover, there are a lot of variables in the normal operation of the building which can be simulated but in real life is difficult to control without intelligent controllers. The prerequisite of the intelligent controller can be hugely divided into two: an initial parameter identification which will get info of the building as soon as it is installed in the house via small tests, sensors and user input; then a moving variable which will be gathered from the usage, monitoring system and user validation which will be continuously improved. The first step of an intelligent controller will be able to learn the environment such as building location, building orientation, infiltration, $U$ value, energy losses, $g$ values, solar gains, heating response of the building, energy system 
Fig. 11 A transition (autumn and spring) week's simulation results showing the building demand responses for each standard

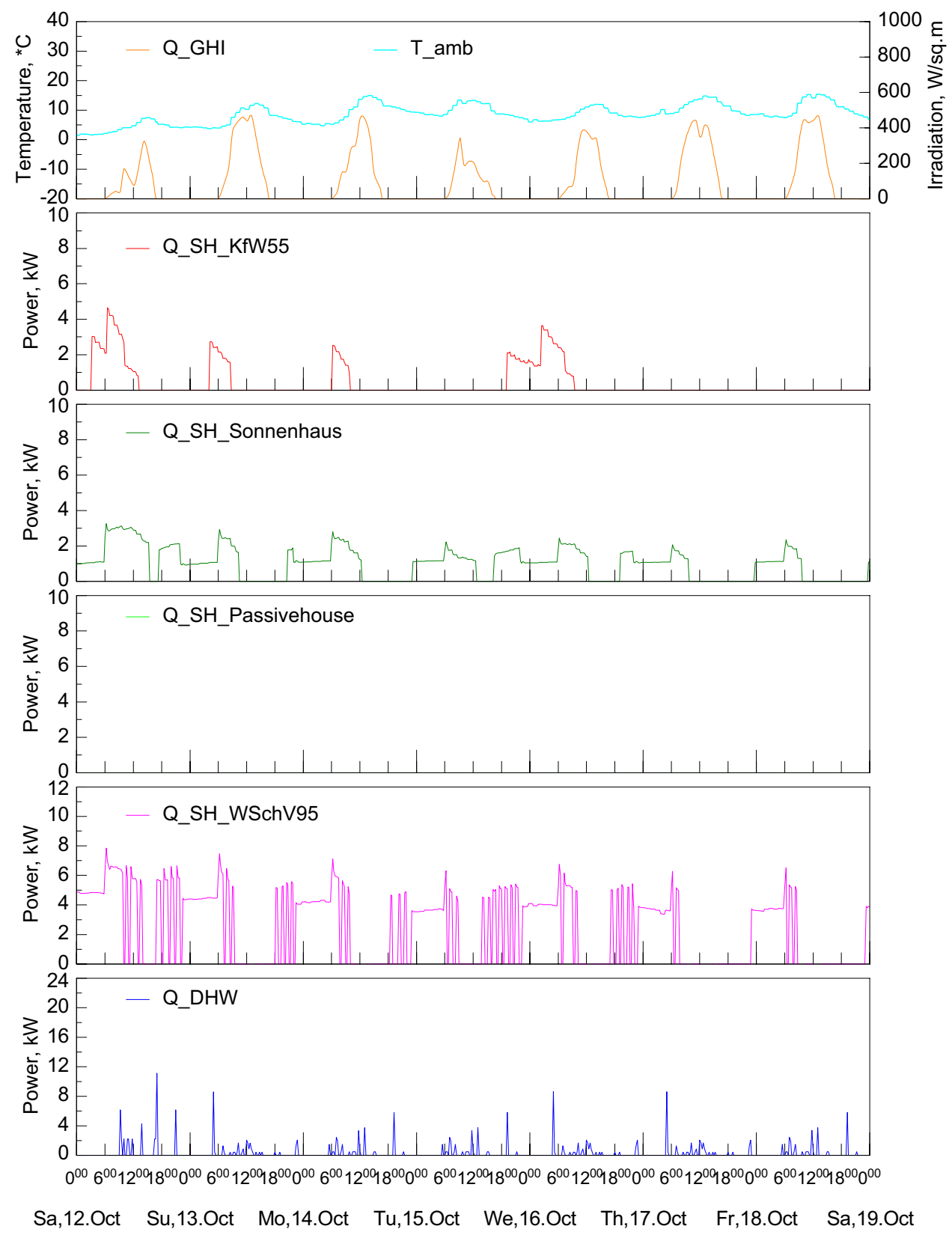

components and their size. The continuous improvement of the conditions has to be done to the person gains, ventilation, heating power and slope, grid and gas price, heating response with respect to ambient temperature and energy loss, part of the building with respect to time, etc. With the help of MPC and the parameters read from the system, the control logic should be flexible to take decisions with the forecasted energy demand, and with respect to all these, the energy production should be planned accordingly. As it is seen in the above case study, the transition season is the most important to gain an increased renewable fraction and efficient energy utilization.

\section{Conclusion}

As for the differences in the building itself, it can be seen that their responses for the change in the climatic conditions are different. For the space heating, the passive house is the best, but when closely looked into, it can be noticed for such a house the SH power cannot be as high as a WSchVO95 while the building cannot store a lot of heat due to the heavy insulation and airtightness. In addition, the ventilation is more important in passive house and KfW55 than other two standards while it is forced ventilation and should take care of the comfort of the persons living there. Sonnenhaus is 
also a good efficient house but for some small discrepancies, these houses are not as efficient as KfW55 and passive house which is already discussed in section 'Sonnenhaus results'. In terms of control logic, a lot of changes have to be made between the different buildings. For example, as seen here, the gas boiler sensor in the tank, the mass flow and the set point temperature had to be changed according to building type. These are due to the account of the changes in the mass flow in the floor/radiator heating along with the power required by the space heating. The comparison of the building and their optimized energy system shows that for each of the building type, the response and demand of the building is different. Thus, the control strategy is important and a simple on/off controller does not satisfy the needs. With this simulation study, the importance of buildings in an energy system is emphasized.

Even though KfW55 and passive house have less energy requirement, they are vulnerable to small changes in the parameters such as occupant behavior and ventilation frequency. Thus, the heating control has to adapt to the situation and heat up the space according to the current requirement. It cannot be expected that the building could store heat is high. To move over to the next step of efficiency, the transition seasons energy production and demand management needs to be more precise, this can be done cleverly with selflearning controllers with continuous improvement which uses the service of monitoring, MPC, energy and demand forecast and user inputs. In addition, the MPC control unit should be universal so that it can adapt to the system locally.

As in the paper, a demonstrator system with all the components is built up at Sailer GmbH's premises. The system will be emulated for a single family house demand with a kind of HiL setup where the control logic of the system will be developed and tested. Thus, the different approaches for different buildings where a single flexible control logic will adapt to the system can be developed. To further develop the model, the simulation will be compare with the real-time data from the demonstrator and the simulation model will be tuned for a much precise operation.

Acknowledgements The work (partially) described in this paper is a part of the project 'Intelligentes Heimenergiemanagement (iHEM)' and the Research Initiative 'Energiespeicher' funded by the Bundesministerium für Wirtschaft und Energie under the Project Number-03ET1205F.

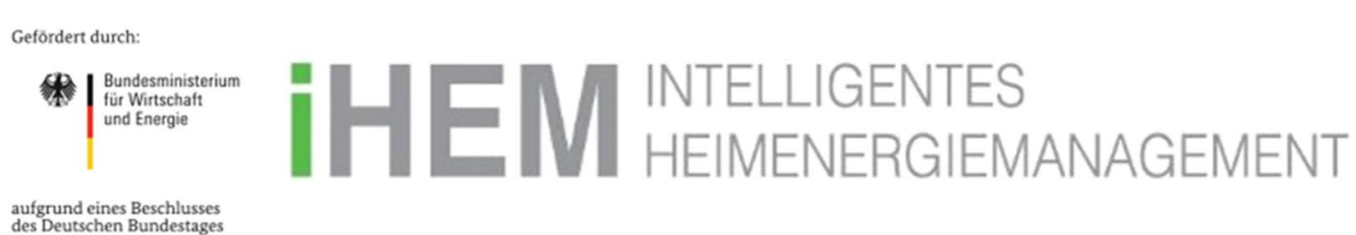

using thermal mass, since the building is too sensitive and the thermal comfort zone is very small. On the other hand, the WSchVO95 and Sonnenhaus are buildings with high heating energy demand and the building can be used to store heat in the thermal mass. With the WSchVO95 building having a large amount of space heating demand, the energy system should be sized for the requirement. The unexpected results are from the Sonnenhaus building, this building even though has less $U$ value envelope, the space heating demand in a year is c.a. twice as much as KfW55. The main reason for it is that of the heat exchanger in the ventilation system. In KfW55, there is an electrical heat exchanger which has a forced ventilation and will exchange heat from the outlet air pipe. Thus reducing the heat demand. Moreover, in Sonnenhaus, the solar fraction should be $50 \%$ and for this the system has to be sized bigger than that for the other building types.

This simulation case study pronounces the importance of buildings in the energy system design and why space heatings are a node point for a better efficient system. This is difficult since buildings are not always the same and react differently for different scenarios and building types, thus the necessity of an intelligent control system for this purpose
Open Access This article is distributed under the terms of the Creative Commons Attribution 4.0 International License (http://creativeco mmons.org/licenses/by/4.0/), which permits unrestricted use, distribution, and reproduction in any medium, provided you give appropriate credit to the original author(s) and the source, provide a link to the Creative Commons license, and indicate if changes were made.

\section{References}

1. Laustsen, J.: Energy efficiency requirements in building codes, energy efficiency policies for new buildings. Int. Energy Agency IEA 2, 477-488 (2008)

2. IEA.: Energy Technology Perspectives. International Energy Agency, (2006)

3. dena, "Der dena-Gebäudereport 2015- Statistiken und Analysen zur Energieeffizienz im Gebäudebestand.” Deutsche EnergieAgentur, 2015

4. Clarke, J.A., Johnstone, C.M., Kelly, N.J., Strachan, P.A., Tuohy, P.: The role of built environment energy efficiency in a sustainable UK energy economy. Energy Policy 36(12), 4605-4609 (2008)

5. Balaras, C.A., Gaglia, A.G., Georgopoulou, E., Mirasgedis, S., Sarafidis, Y., Lalas, D.P.: European residential buildings and empirical assessment of the Hellenic building stock, energy consumption, emissions and potential energy savings. Build. Environ. 42(3), 1298-1314 (2007) 
6. ARGE eV, "Wohngebäude-Fakten 2016. Eine Analyse des Wohngebäudezustandes in Deutschland." Arbeitsgemeinschaft für zeitgemäßes Bauen e.V., 2016

7. Enteria, N., Awbi, H., Yoshino, H.: Application of renewable energy sources and new building technologies for the Philippine single family detached house. Int. J. Energy Environ. Eng. 6(3), 267-294 (2015)

8. Enteria, N., Yoshino, H., Satake, A., Takaki, R., Ishihara, H., Baba, S.: Benefits of utilizing on-site and off-site renewable energy sources for the single family detached house. Int. J. Energy Environ. Eng. 7(2), 145-166 (2016)

9. Prívara, S., Cigler, J., Váňa, Z., Oldewurtel, F., Sagerschnig, C., Žáčeková, E.: Building modeling as a crucial part for building predictive control. Energy Build. 56, 8-22 (2013)

10. Le Dréau, J., Heiselberg, P.: Energy flexibility of residential buildings using short term heat storage in the thermal mass. Energy 111, 991-1002 (2016)

11. Yu (Jerry), Z., Huang, G., Haghighat, F., Li, H., Zhang, G.: Control strategies for integration of thermal energy storage into buildings: State-of-the-art review. Energy Build. 106, 203-215 (2015)

12. Thieblemont, H., Haghighat, F., Ooka, R., Moreau, A.: Predictive control strategies based on weather forecast in buildings with energy storage system: a review of the state-of-the art. Energy Build. 153, 485-500 (2017)

13. Henze, G.P., Schoenmann, J.: Evaluation of reinforcement learning control for thermal energy storage systems. HVACR Res. 9(3), 259-275 (2003)

14. Aström, K.J., Wittenmark, B.: Adaptive Control: Second Edition. [Online]. Available: http://store.doverpublications.com/04864 62781.html. Accessed 28 Aug 2017

15. Kirk, D.E.: Optimal Control Theory: An Introduction. [Online]. Available: http://store.doverpublications.com/0486434842.html. Accessed 28 Aug 2017

16. Reynders, G., Nuytten, T., Saelens, D.: Potential of structural thermal mass for demand-side management in dwellings. Build. Environ. 64, 187-199 (2013)

17. Sturzenegger, D., Gyalistras, D., Morari, M., Smith, R.S.: Model predictive climate control of a Swiss Office Building: implementation, results, and cost-benefit analysis. IEEE Trans. Control Syst. Technol. 24(1), 1-12 (2016)

18. Photovoltaik Augsburg: Solarthermie, PhotovoltaikanlageiHEM. [Online]. Available: http://www.ihem.eu/. Accessed: 13 Jan 2017

19. Narayanan, M., Mengedoht, G., Commerell, W., Design of simulation model for novel solar thermal storage tank. In: Simulation Technischer SYSTEME-Grundlagen und Methoden in Modellbildung und Simulation, Ulm, Germany, (2017)

20. Narayanan, M., Mengedoht, G., Commerell, W., Simulation and design of an energy system with solar collectors, PV, fuel cell $\mathrm{CHP}$ and gas boiler at Ehingen, Germany. Presented at the 13th International Conference on Heat Engines and Environmental Protection, Budapest, Hungary, (2017)

21. Gerster, J., Blank, M., Stern, K., Sonnenschein, M.: Intelligentes Heimenergiemanagement - Nutzung der Synergiepoten-tiale bei der thermischen und elektrischen Objektversorgung durch modellbasierte und prädiktive Betriebsführungsstrategien. Mannheim, Germany, 11 Jul 2016

22. Julia 1-3-Dammann-Haus. [Online]. Available: https://www. dammann-haus.de/julia-1-3.html?articles=julia-1-3. Accessed 08 Jun 2018

23. “VDI4655 Richtlinie," Verein Deutscher Ingenieure e.V. [Online]. Available:/nc/richtlinie/vdi_4655-referenzlastprofile_von_ein_ und_mehrfamilienhaeusern_fuer_den_einsatz_von_kwk_anlagen_/. Accessed 22 Jun 2018

24. KfW,: "KfW Anförderungen," KfW55 Anförderungen, 2016. [Online]. Available: https://www.kfw.de/KfW-Konzern/Service/ Download-Center/F\%C3\%B6rderprogramme-(Inlandsf.)-(D-EN)/ Barrierefreie-Dokumente/Energieeffizient-Bauen-(153)-Anlag e-zum-Merkblatt-04-2016/. Accessed 28 Aug 2017

25. Sonnenhaus Institut e.V., (ed.): Neufestlegung der Sonnenhauskriterien für Wohngebäude. (2014)

26. I. des B.- BMUB, "Energieeinsparverordnung." [Online]. Available: http://www.bmub.bund.de/P3427/. Accessed 28 Aug 2017

27. Passivhaus Institut: Qualitätsanforderungen an Passivhäuser. Qualitätsanforderungen an Passivhäuser, 28 Aug 2016. [Online]. Available: http://www.passiv.de/de/02_informationen/02_quali taetsanforderungen/02_qualitaetsanforderungen.htm. Accessed 28 Aug 2017

28. EnEG.: Die Wärmeschutzverordnung 1995, Anlagen 1 bis 4. (1994)

29. TRNSYS: Transient System Simulation Tool-TRNSYS. Madison USA.: Thermal Energy System Specialists, LLC. (2014)

30. Sailer GmBH-Focus: Sailer GmbH Ehingen-Solar collectors. [Online]. Available: http://www.sailergmbh.de/en/products/solar -collectors.html. Accessed 29 Aug 2017

31. Drück, H.: Multiport store model for TRNSYS - type 340. Institut für Thermodynamik und Wärmetecknik (ITW), Universität Stuttgart, (2006)

32. Sailer GmBH-Quattro, Sailer GmbH Ehingen-Schichtenspeicher. [Online]. Available: http://www.sailergmbh.de/en/products/schic htenspeicher/schichtenspeicher.html. Accessed 13 Jan 2017

33. Solid Power: SOLIDpower_BlueGEN_Brochure_UK_web.pdf. [Online]. Available: http://www.solidpower.com/fileadmin/user_ upload/pages/Logos_materialien/SOLIDpower_BlueGEN_Broch ure_UK_web.pdf. Accessed 23 May 2017

34. Sailer GmBH -FriWasta, Sailer GmbH Ehingen-Frischwasserstation. [Online]. Available: http://www.sailergmbh.de/it/produkte/ frischwasserstation.html. Accessed 30 Aug 2017

35. Aleo Solar.: "aleo_S19_295_300 W.pdf." [Online]. Available: http://www.novisenergy.ch/pdf/aleo_S19_295_300W.PDF. Accessed 23 May 2017

Publisher's Note Springer Nature remains neutral with regard to jurisdictional claims in published maps and institutional affiliations. 